\title{
Supporting Information for Design Principles for Aqueous Na-ion Battery Cathodes
}

Xingyu Guo, ${ }^{\dagger}$ Zhenbin Wang, ${ }^{\ddagger}$ Zhi Deng, ${ }^{\ddagger}$ Bo Wang, ${ }^{\top}$ Xi Chen, ${ }^{\top}$ and Shyue Ping Ong*,‡

$\dagger$ †aterials Science and Engineering Program, University of California San Diego, 9500 Gilman Dr, Mail Code 0448, La Jolla, CA 92093-0448, United States

$\ddagger$ Department of NanoEngineering, University of California San Diego, 9500 Gilman Dr,

Mail Code 0448, La Jolla, CA 92093-0448, United States

ฯGEIRI North America, San Jose, CA 95134, USA

E-mail: ongsp@eng.ucsd.edu 


\section{Calculated binary phase diagrams of all compounds}

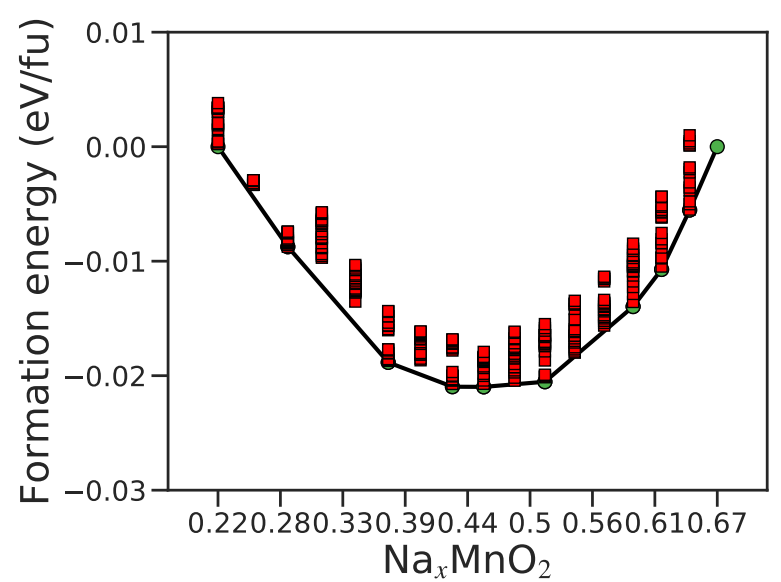

(a) Convex hull of $\mathrm{Na}_{x} \mathrm{MnO}_{2}$

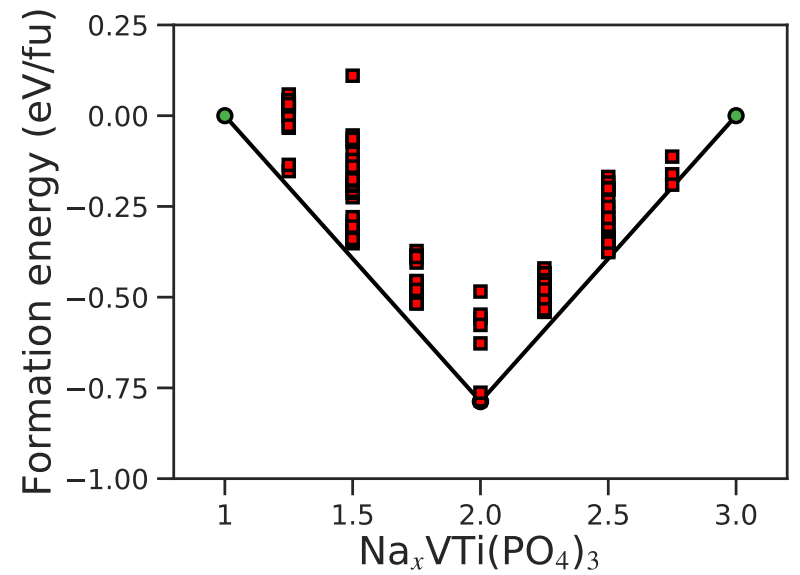

(c) Convex hull of $\mathrm{Na}_{x} \mathrm{VTi}\left(\mathrm{PO}_{4}\right)_{3}$

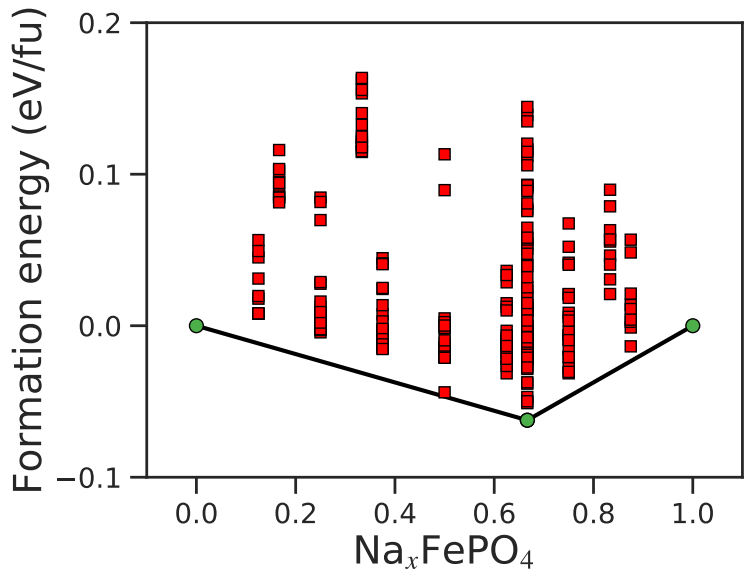

(e) Convex hull of $\mathrm{Na}_{x} \mathrm{FePO}_{4}$

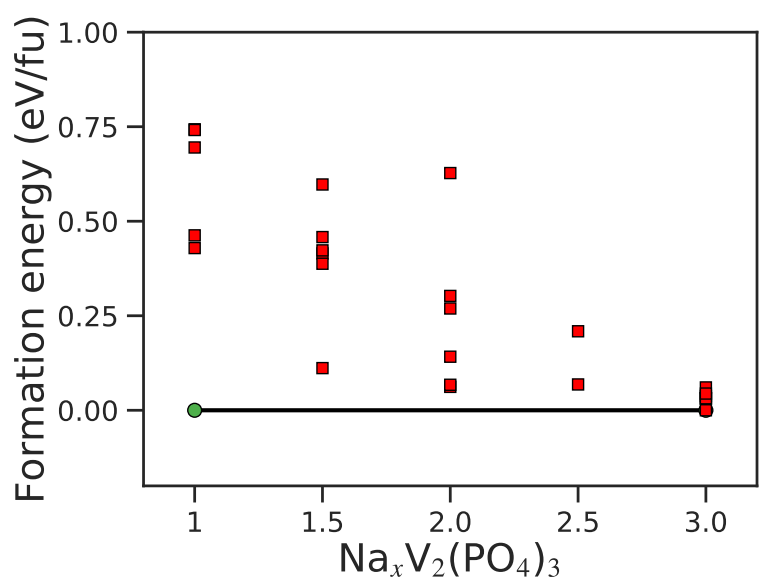

(b) Convex hull of $\mathrm{Na}_{x} \mathrm{~V}_{2}\left(\mathrm{PO}_{4}\right)_{3}$

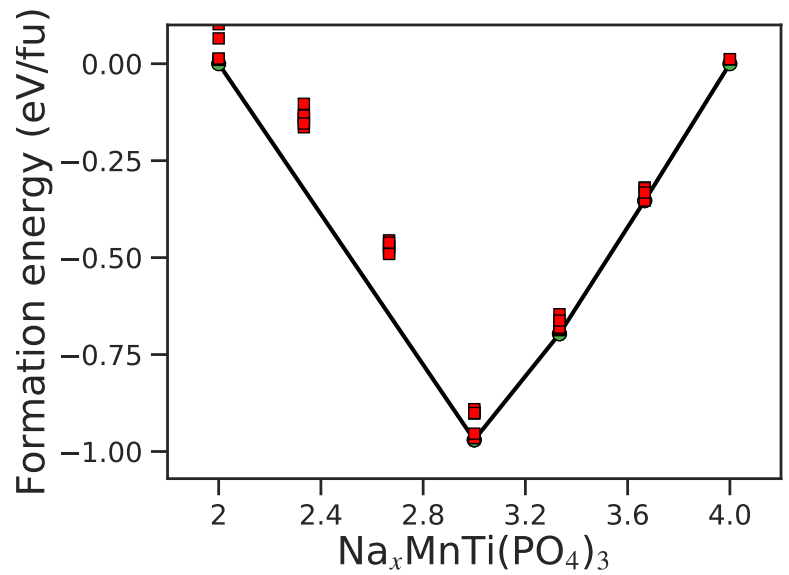

(d) Convex hull of $\mathrm{Na}_{x} \mathrm{MnTi}\left(\mathrm{PO}_{4}\right)_{3}$

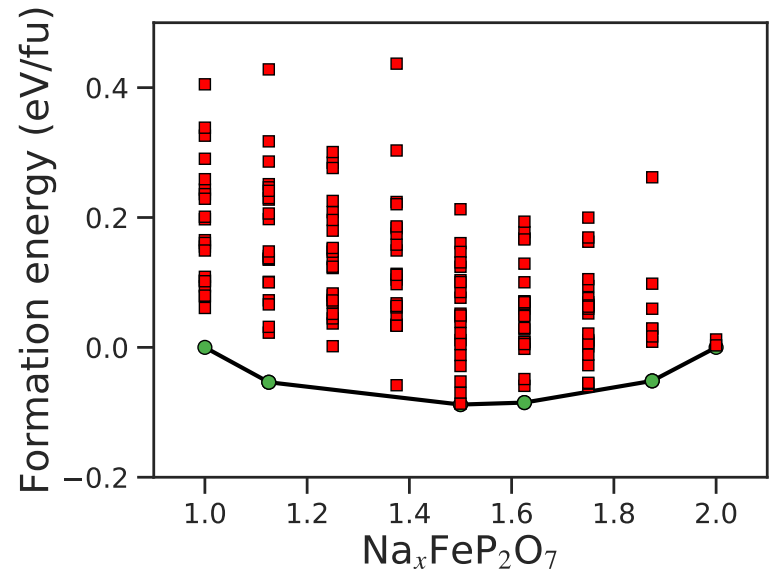

(f) Convex hull of $\mathrm{Na}_{x} \mathrm{FeP}_{2} \mathrm{O}_{7}$ 


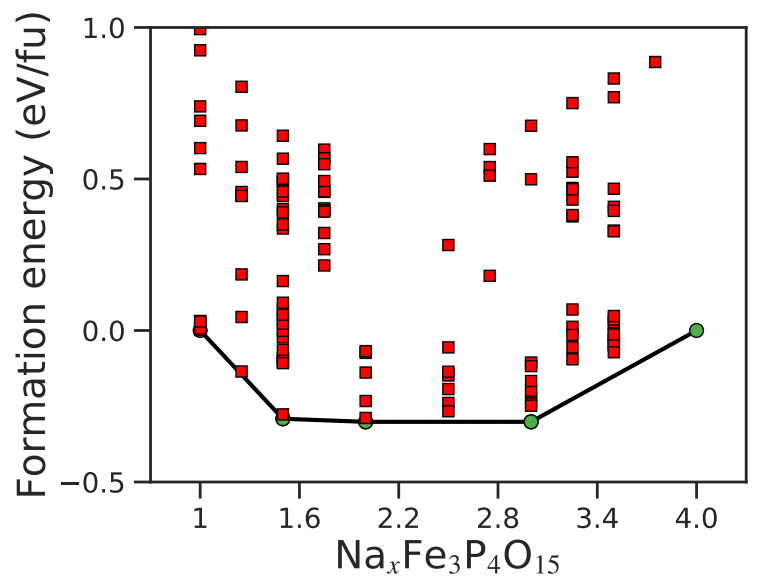

(g) Convex hull of $\mathrm{Na}_{x} \mathrm{Fe}_{3} \mathrm{P}_{4} \mathrm{O}_{15}$

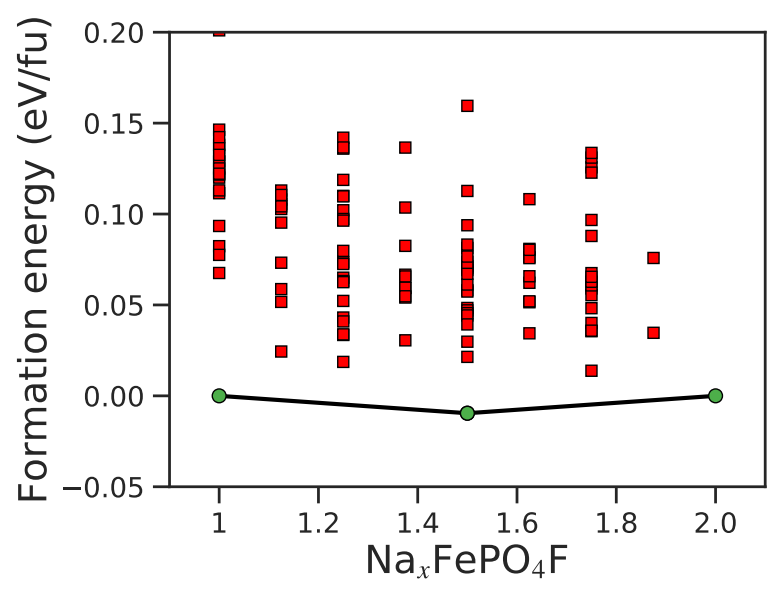

(i) Convex hull of $\mathrm{Na}_{\mathrm{x}} \mathrm{FePO}_{4} \mathrm{~F}$

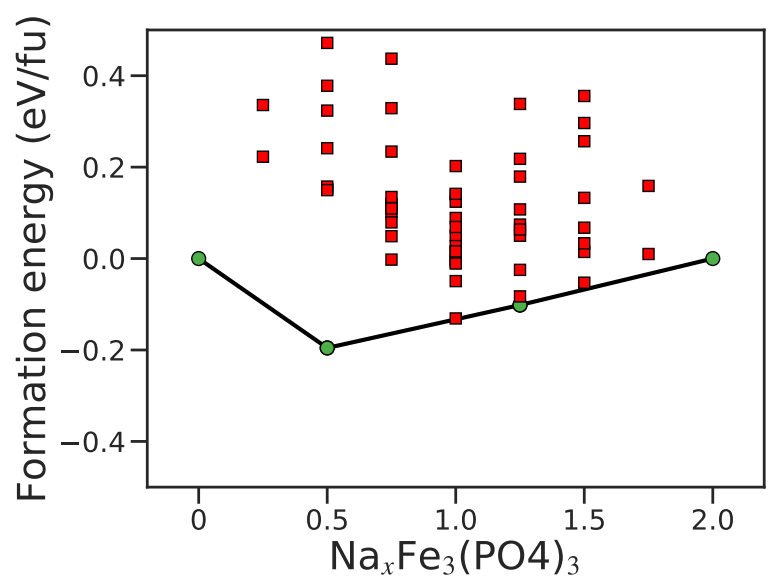

(k) Convex hull of $\mathrm{Na}_{x} \mathrm{Fe}_{3}\left(\mathrm{PO}_{4}\right)_{3}$

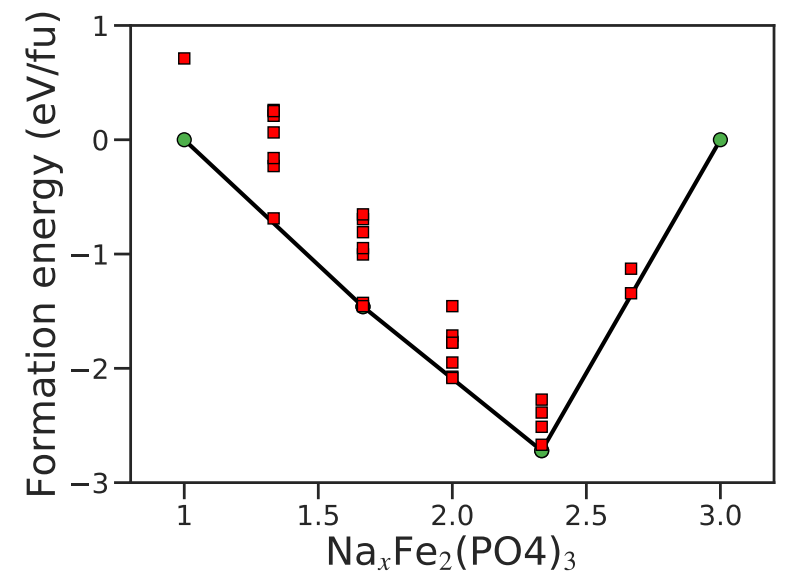

(h) Convex hull of $\mathrm{Na}_{x} \mathrm{Fe}_{2}\left(\mathrm{PO}_{4}\right)_{3}$

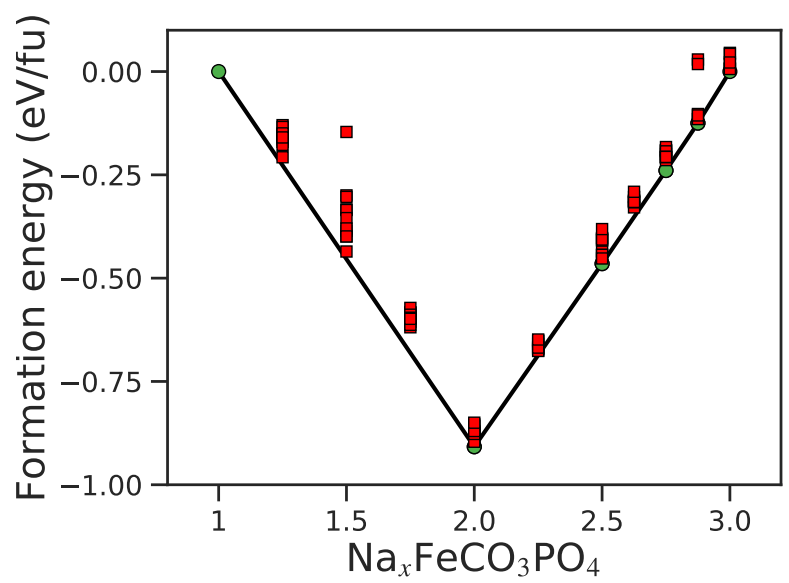

(j) Convex hull of $\mathrm{Na}_{x} \mathrm{FeCO}_{3} \mathrm{PO}_{4}$

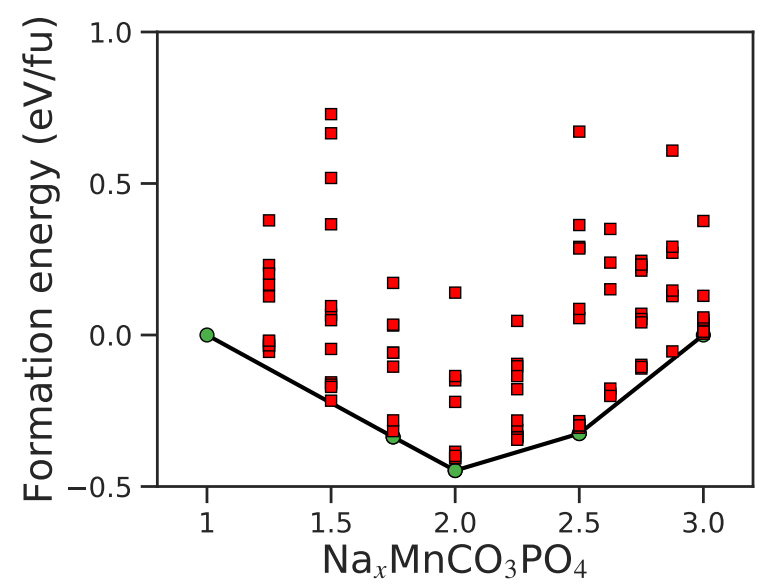

(l) Convex hull of $\mathrm{Na}_{x} \mathrm{MnCO}_{3} \mathrm{PO}_{4}$

Figure S1: Calculated convex hull 


\section{Notes on the calculated convex hulls and voltage profiles}

$\mathrm{Na}_{\mathbf{0 . 4 4}} \mathrm{MnO}_{2}$. In experiment, there are at least six intermediate phases identified for $\mathrm{Na}_{0.44} \mathrm{MnO}_{2}$ during charge/discharge processes. ${ }^{1}$ In our calculations, we predicted eight intermediate stable phases within the composition range of $\mathrm{Na}_{0.22} \mathrm{MnO}_{2} \sim \mathrm{Na}_{0.66} \mathrm{MnO}_{2}$. Similarly, Kim et al. ${ }^{2}$ reported six calculated intermediate stable phases within the same composition range. Our calculated voltage profile is consistent with the experimental results. (Figure $3(\mathrm{a}))$

$\mathrm{Na}_{\mathbf{3}} \mathrm{V}_{\mathbf{2}}\left(\mathrm{PO}_{4}\right)_{3}$. NASICON-type $\mathrm{Na}_{3} \mathrm{~V}_{2}\left(\mathrm{PO}_{4}\right)_{3}$ was reported to exhibit reversible phase transition from $\mathrm{NaV}_{2}\left(\mathrm{PO}_{4}\right)_{3}$ to $\mathrm{Na}_{3} \mathrm{~V}_{2}\left(\mathrm{PO}_{4}\right)_{3}$ during charge/discharge processes with a single voltage plateau at $3.39 \mathrm{~V}$ vs Na/Na ${ }^{+} .{ }^{3}$ According to our calculated convex hull, no stable intermediate phase is found between $\mathrm{NaV}_{2}\left(\mathrm{PO}_{4}\right)_{3}$ and $\mathrm{Na}_{3} \mathrm{~V}_{2}\left(\mathrm{PO}_{4}\right)_{3}$, which is also in line with the computational results by Lim et al. ${ }^{4}$.

$\mathrm{Na}_{2} \mathrm{FeP}_{2} \mathrm{O}_{7}$. Ex situ XRD characterization indicates that $\mathrm{Na}_{2} \mathrm{FeP}_{2} \mathrm{O}_{7}$ undergoes successive biphasic transitions via various intermediate phases. ${ }^{5}$ Four voltage plateaus located at 2.52, 2.99, 3.08 and $3.24 \mathrm{~V}$ vs Na/Na $\mathrm{Na}^{+}$have been observed in experiments. Our calculations showed that four intermediate stable phases with respect to $\mathrm{Na}_{2} \mathrm{FeP}_{2} \mathrm{O}_{7}$ and $\mathrm{NaFeP}_{2} \mathrm{O}_{7}$ and the calculated voltage profile shows five plateaus at 2.405, 2.694, 2.793, 2.910 and $3.247 \mathrm{~V}$ vs $\mathrm{Na} / \mathrm{Na}^{+}$, which are close to the experimental results. The only difference is that the experimental capacity drops rapidly when the voltage is lower than $2.99 \mathrm{~V} \mathrm{vs} \mathrm{Na} / \mathrm{Na}^{+}$. Previous calculations by Kim et al. ${ }^{5}$ also suggested four intermediate stable phases but with slightly different compositions.

$\mathrm{NaFePO}_{4}$. In our calculation, there is a stable phase at $\mathrm{Na}_{2 / 3} \mathrm{FePO}_{4}$, which is in line with the previous experimental ${ }^{6}$ and calculation results. ${ }^{7}$ The calculated voltage profiles

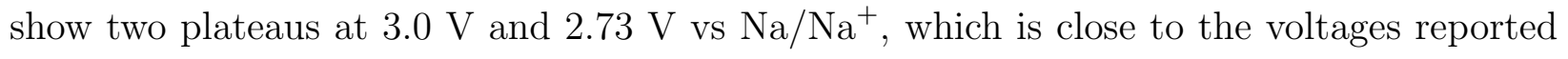
experimentally. ${ }^{8}$

$\mathrm{Na}_{2} \mathrm{FePO}_{4} \mathbf{F}$. Li et al. ${ }^{9}$ have shown that $\mathrm{Na}_{2} \mathrm{FePO}_{4} \mathrm{~F}$ exhibits two two-phase reactions and form $\mathrm{Na}_{1.5} \mathrm{FePO}_{4} \mathrm{~F}$ intermediate phase at low $\mathrm{C}$ rate $(0.1 \mathrm{C} \sim 1 \mathrm{C})$. In our calculations, we 
predicted there is only one stable phase at $\mathrm{Na}_{1.5} \mathrm{FePO}_{4} \mathrm{~F}$, which is in line with experimental ${ }^{9}$ and the computational results. ${ }^{10}$ The calculated voltage profile shows two plateau at 2.87 and $2.91 \mathrm{~V}$ vs Na/Na+, which is close to the experimental results of 2.91 and $3.06 \mathrm{~V}$ vs $\mathrm{Na} / \mathrm{Na}^{+} \cdot 9$ 


\section{Calculated voltage profile of $\mathrm{Na}_{\mathrm{x}} \mathrm{MnO}_{2}$ in basic elec- trolyte}

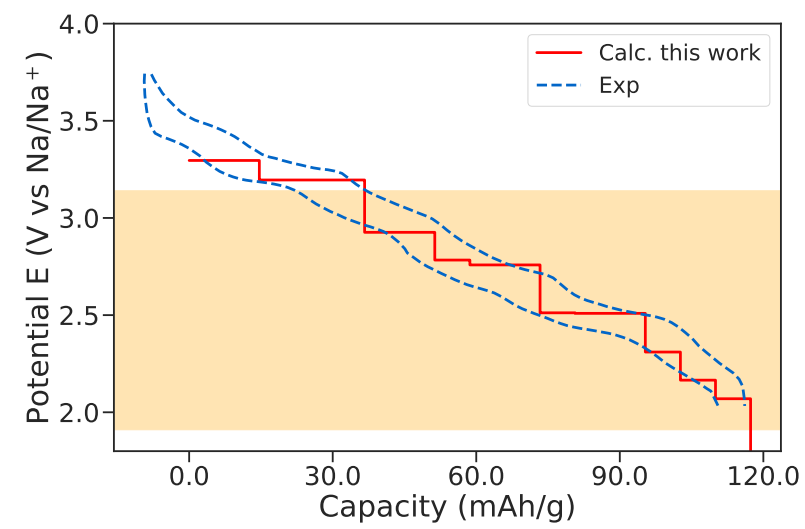

Figure S2: Calculated voltage profile of $\mathrm{Na}_{x} \mathrm{MnO}_{2}(x=0.22-0.66)$. The electrochemical stability windows at $\mathrm{pH}=13.5$ are shaded orange. The experimental voltage profile is from ref 2 . 


\section{Calculated voltage profiles, Pourbaix diagram and $\Delta G_{p b x}$ of $\mathrm{Na}_{3} \mathrm{MnTi}\left(\mathrm{PO}_{4}\right)_{3}$ cathode}

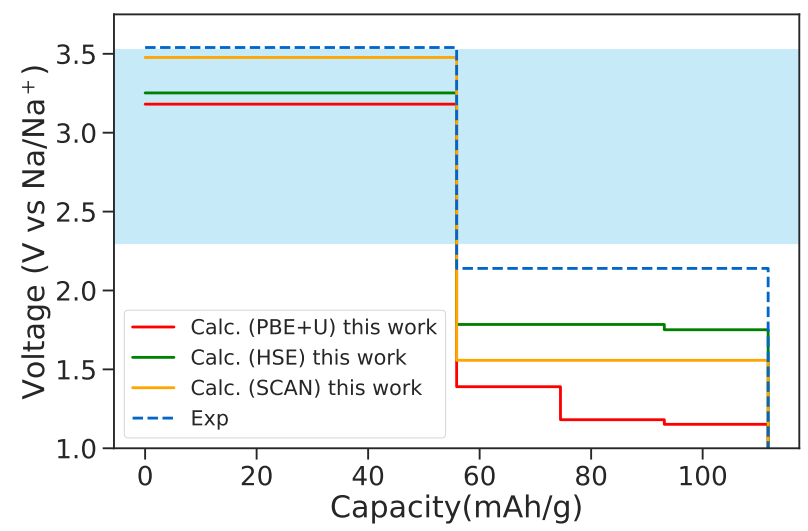

(a)

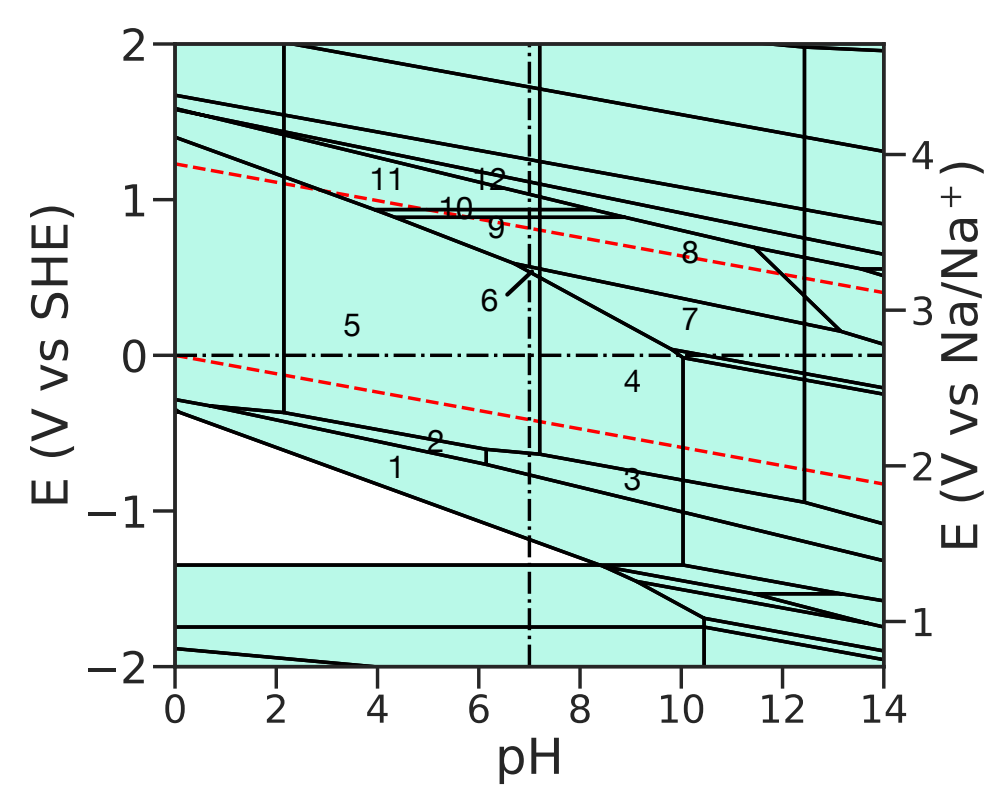

1. $\mathrm{Na}^{+}+\mathrm{Mn}^{2+}+\mathrm{TiO}_{2}(\mathrm{~s})+\mathrm{PH}_{3}(\mathrm{aq})$

2. $\mathrm{Na}^{+}+\mathrm{Mn}^{2+}+\mathrm{TiO}_{2}(\mathrm{~s})+\mathrm{H}_{2} \mathrm{PO}_{3}^{-}$

3. $\mathrm{Na}^{+}+\mathrm{Mn}^{2+}+\mathrm{TiO}_{2}(\mathrm{~s})+\mathrm{HPO}_{3}^{2-}$

4. $\mathrm{Na}^{+}+\mathrm{Mn}^{2+}+\mathrm{TiO}_{2}(\mathrm{~s})+\mathrm{HPO}_{4}{ }^{2-}$

5. $\mathrm{Na}^{+}+\mathrm{Mn}^{2+}+\mathrm{TiO}_{2}(\mathrm{~s})+\mathrm{H}_{2} \mathrm{PO}_{4}^{-}$

6. $\mathrm{Na}^{+}+\mathrm{Mn}_{2} \mathrm{O}_{3}(\mathrm{~s})+\mathrm{TiO}_{2}(\mathrm{~s})+\mathrm{H}_{2} \mathrm{PO}_{4}^{-}$

7. $\mathrm{Na}^{+}+\mathrm{Mn}_{2} \mathrm{O}_{3}(\mathrm{~s})+\mathrm{TiO}_{2}(\mathrm{~s})+\mathrm{HPO}_{4}{ }^{2-}$

8. $\mathrm{Na}^{+}+\mathrm{NaMn}_{8} \mathrm{O}_{16}(\mathrm{~s})+\mathrm{TiO}_{2}(\mathrm{~s})+\mathrm{HPO}_{4}{ }^{2-}$

9. $\mathrm{Na}^{+}+\mathrm{NaMn}_{8} \mathrm{O}_{16}(\mathrm{~s})+\mathrm{TiO}_{2}(\mathrm{~s})+\mathrm{H}_{2} \mathrm{PO}_{4}{ }^{-}$

10. $\mathrm{Na}^{+}+\mathrm{NaMn}_{16} \mathrm{O}_{32}(\mathrm{~s})+\mathrm{TiO}_{2}(\mathrm{~s})+\mathrm{H}_{2} \mathrm{PO}_{4}{ }^{-}$

11. $\mathrm{Na}^{+}+\mathrm{MnO}_{2}$ (s) $+\mathrm{TiO}_{2}$ (s) $+\mathrm{HPO}_{4}{ }^{2-}$

12. $\mathrm{Na}^{+}+\mathrm{MnO}_{4}{ }^{-}+\mathrm{TiO}_{2}(\mathrm{~s})+\mathrm{HPO}_{4}{ }^{2-}$

(b) 


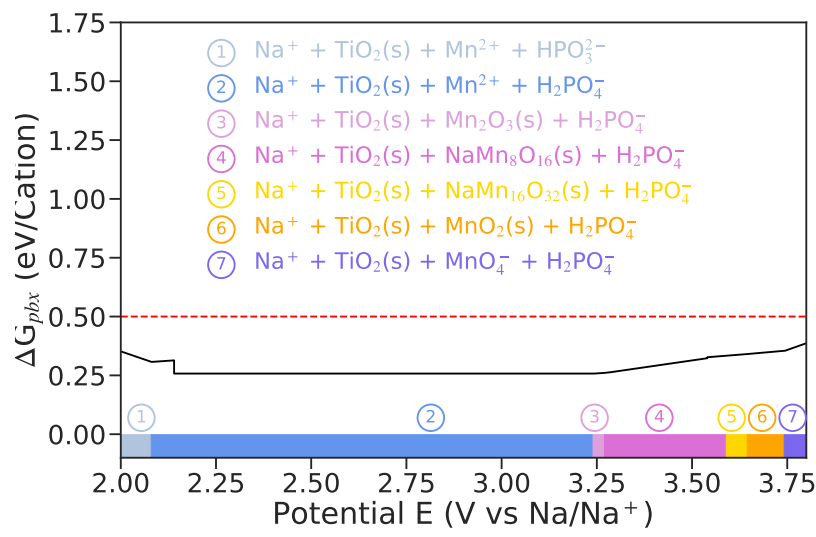

(c)

Figure S3: (a) Voltage profile of $\mathrm{Na}_{x} \mathrm{MnTiP}_{3} \mathrm{O}_{12}$. Electrochemical window $(\mathrm{pH}=7)$ is shaded with blue color. (b) Calculated Pourbaix diagram of $\mathrm{Na}_{3} \mathrm{MnTiP}_{3} \mathrm{O}_{12}$. Regions containing solid phases are shaded with green color. (c) $\Delta G_{p b x}$ of $\mathrm{Na}_{x} \mathrm{MnTiP}_{3} \mathrm{O}_{12}$ as a function of potential in neutral aqueous solution $(\mathrm{pH}=7)$. 


\section{Pourbaix diagram of $\mathrm{Na}_{2} \mathrm{FeP}_{2} \mathrm{O}_{7}$ and $\mathrm{Na}_{4} \mathrm{Fe}_{3} \mathrm{P}_{4} \mathrm{O}_{15}$ cath-}

\section{ode}

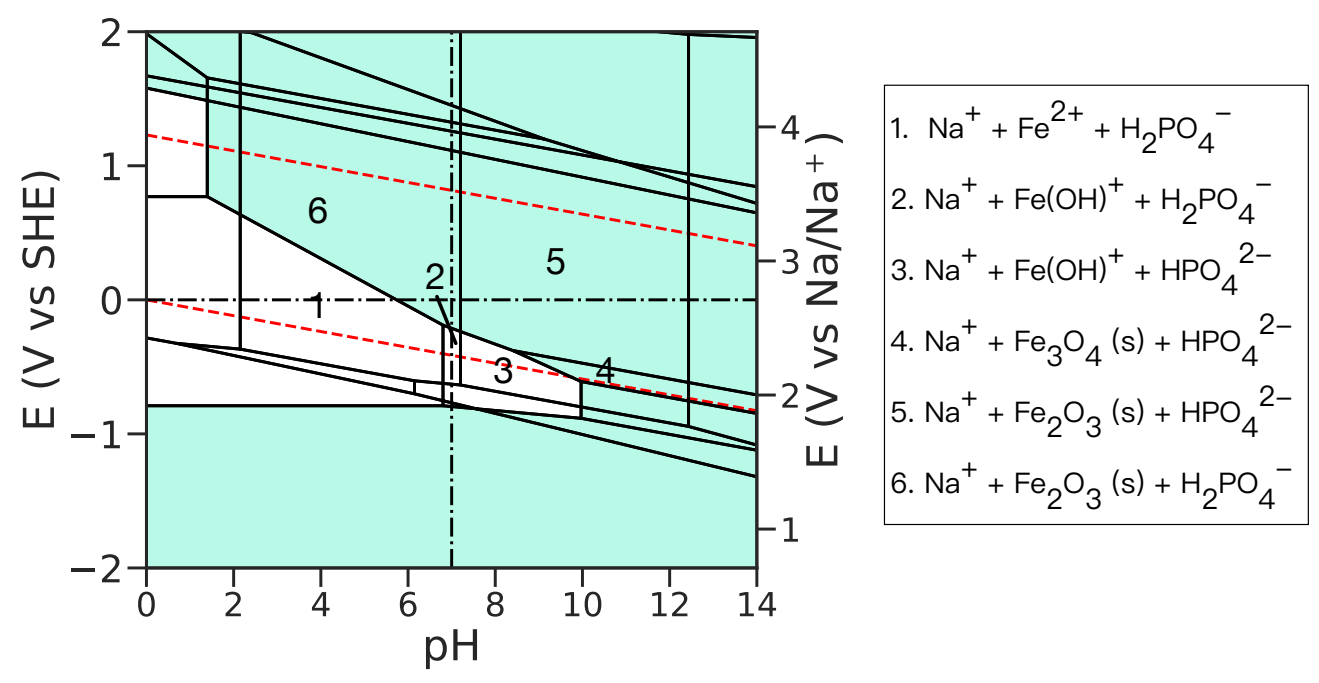

(a) Calculated Pourbaix diagram of $\mathrm{Na}_{2} \mathrm{FeP}_{2} \mathrm{O}_{7}$

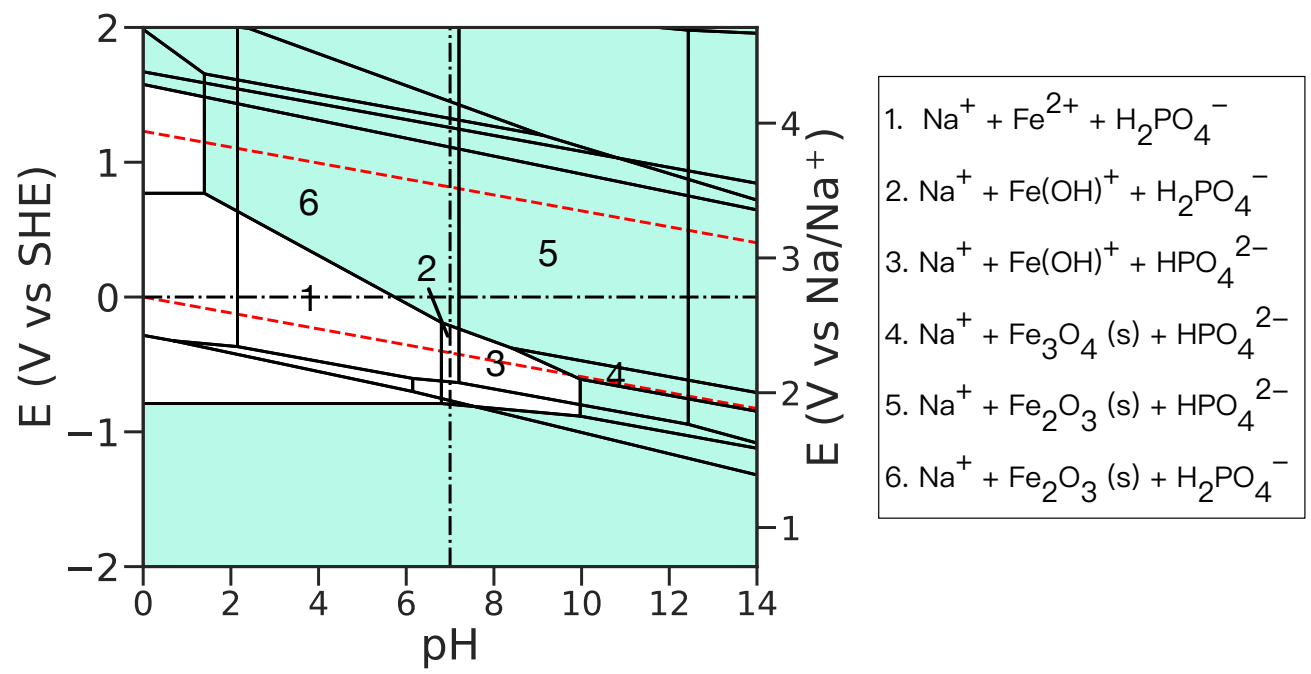

(b) Calculated Pourbaix diagram of $\mathrm{Na}_{4} \mathrm{Fe}_{3} \mathrm{P}_{4} \mathrm{O}_{15}$

Figure S4: Calculated Pourbaix diagram of (a) $\mathrm{Na}_{2} \mathrm{FeP}_{2} \mathrm{O}_{7}$ and (b) $\mathrm{Na}_{4} \mathrm{Fe}_{3} \mathrm{P}_{4} \mathrm{O}_{15}$. Regions containing solid phases are shaded green. 


\section{Calculated $\Delta G_{p b x}$ as a function of $\mathrm{pH}$ of selected cathodes at their average voltage}

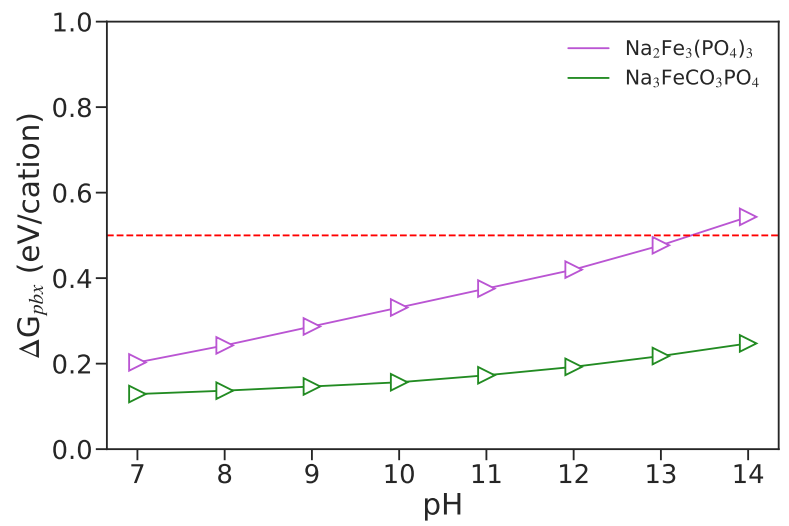

(a)

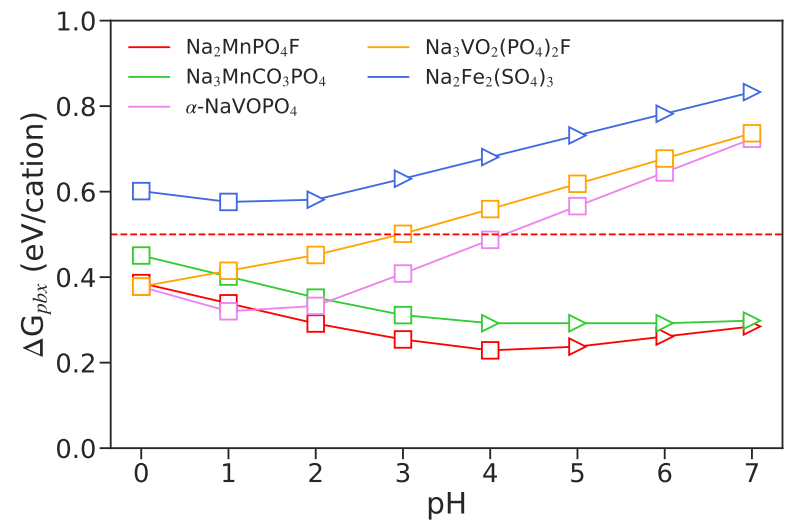

(b)

Figure S5: Calculated $\Delta G_{p b x}$ vs $\mathrm{pH}$ of selected cathodes in (a) basic electrolytes ( $\mathrm{pH}=$ $7 \sim 14)$ (b) acidic electrolytes $(\mathrm{pH}=0 \sim 7)$. Triangle markers indicate the solid phases in decomposition products with $\mathrm{H}_{2} \mathrm{O}$, while square markers indicate non-solid phases in decomposition products. 


\section{Aqueous stability analysis of $\mathrm{Na}_{2} \mathrm{MnPO}_{4} \mathrm{~F}$}

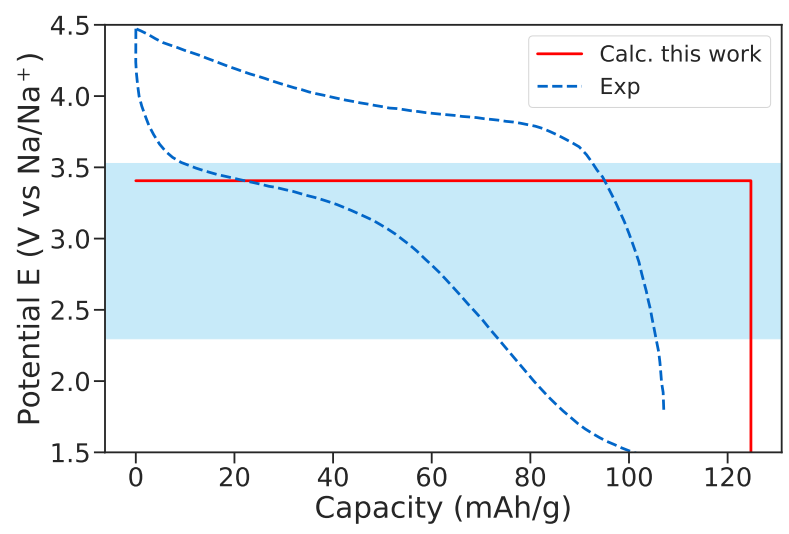

(a) Voltage profile of $\mathrm{Na}_{x} \mathrm{MnPO}_{4} \mathrm{~F}$

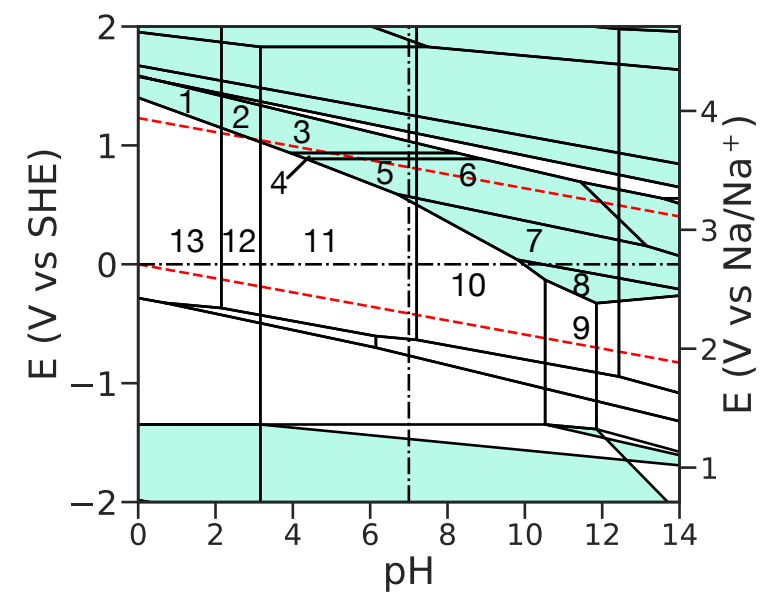

(c) Calculated Pourbaix diagram of $\mathrm{Na}_{2} \mathrm{MnPO}_{4} \mathrm{~F}$

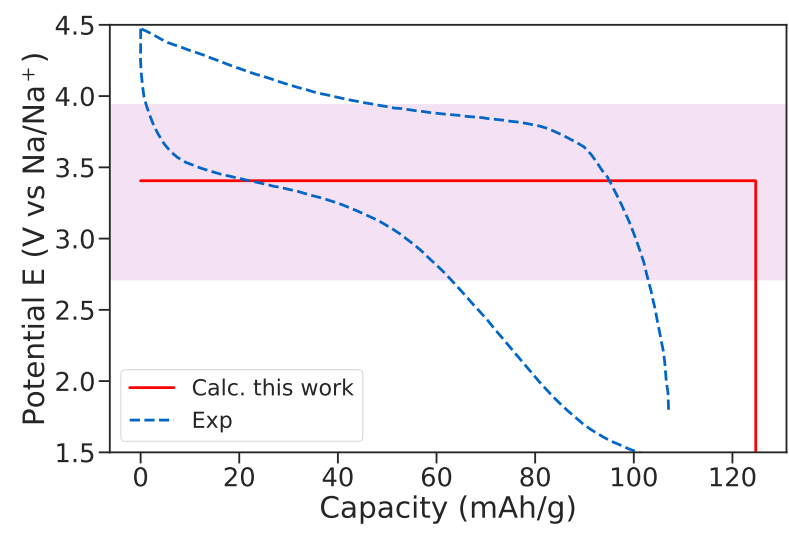

(b) Voltage profile of $\mathrm{Na}_{x} \mathrm{MnPO}_{4} \mathrm{~F}$

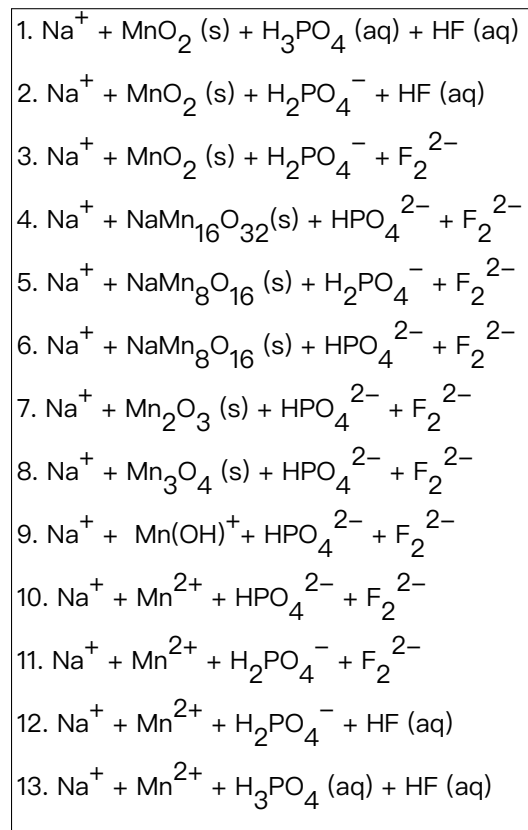




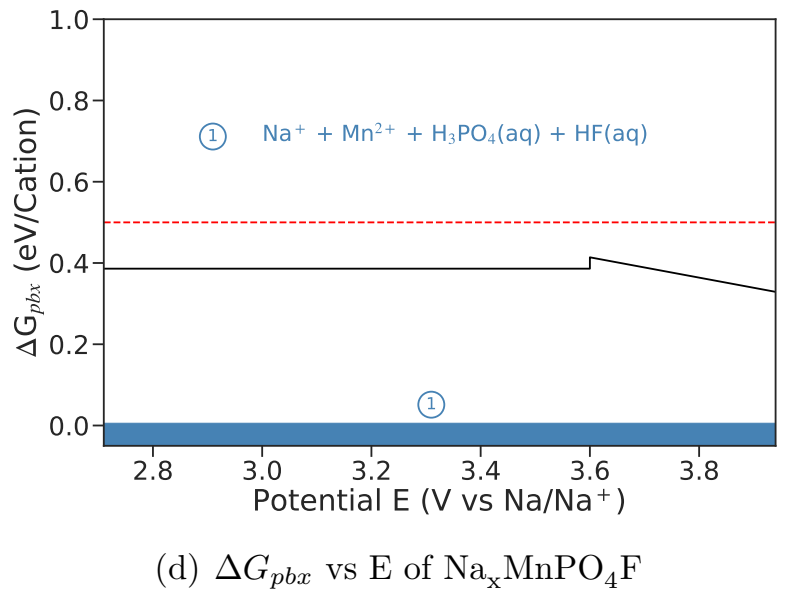

Figure S6: Voltage profile of $\mathrm{Na}_{x} \mathrm{MnPO}_{4} \mathrm{~F}$. Electrochemical window at (a) $\mathrm{pH}=7$ and (b) $\mathrm{pH}=0$ is shaded with blue and pink color, respectively. The experimental voltage profile is from ref 11 (b) Calculated Pourbaix diagram of $\mathrm{Na}_{2} \mathrm{MnPO}_{4} \mathrm{~F}$. Regions containing solid phases are shaded with green color; (c) $\Delta G_{p b x}$ of $\mathrm{Na}_{x} \mathrm{MnPO}_{4} \mathrm{~F}$ as a function of potential in acidic aqueous solution $(\mathrm{pH}=0)$. 


\section{Detailed calculations of the selected promising candi- dates as cathodes in ASIBs}

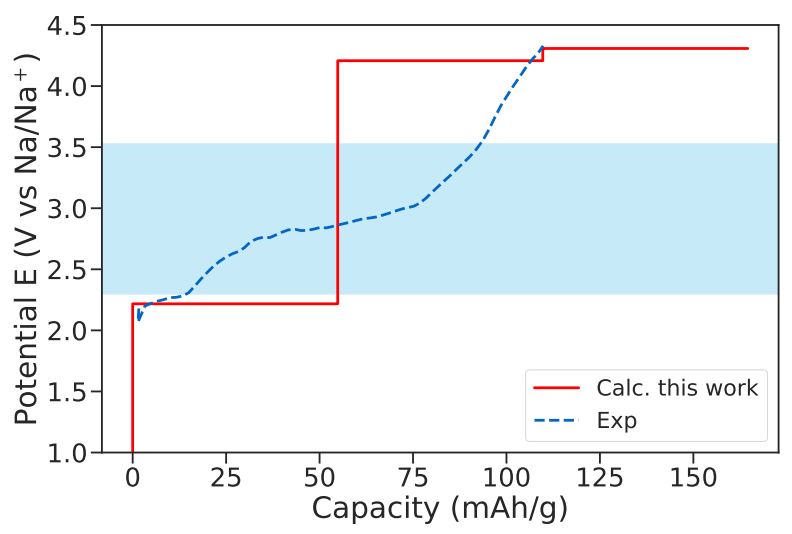

(a) Voltage profile of $\mathrm{Na}_{x} \mathrm{Fe}_{2}\left(\mathrm{PO}_{4}\right)_{3}$

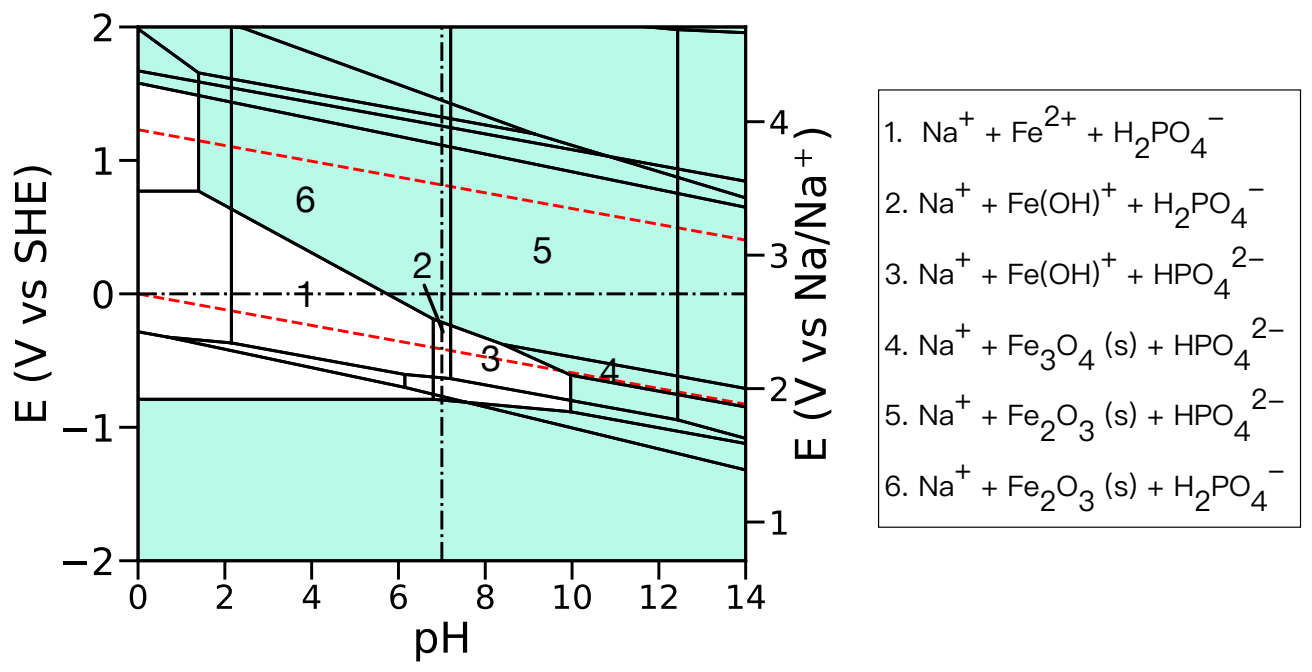

(b) Calculated Pourbaix diagram of $\mathrm{Na}_{3} \mathrm{Fe}_{2}\left(\mathrm{PO}_{4}\right)_{3}$ 


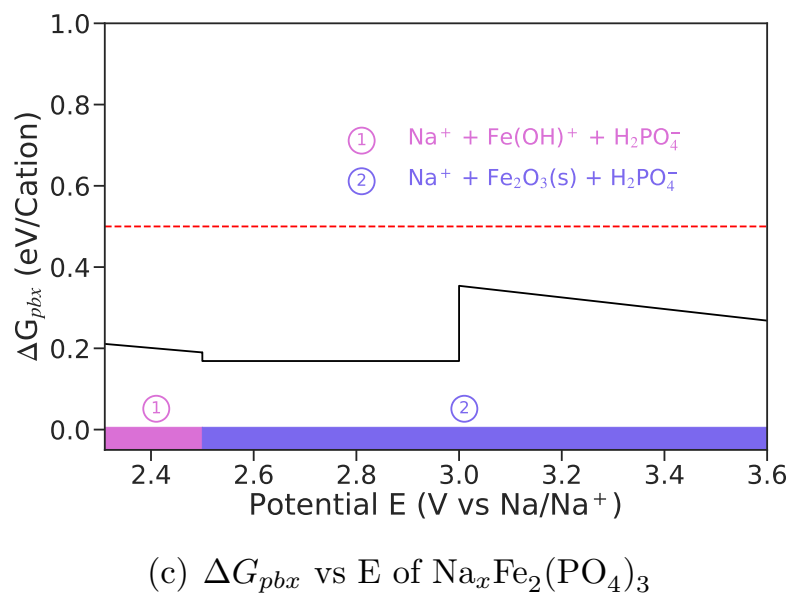

Figure S7: (a) Voltage profile of $\mathrm{Na}_{x} \mathrm{Fe}_{2}\left(\mathrm{PO}_{4}\right)_{3}$. Electrochemical window $(\mathrm{pH}=7)$ is shaded with blue color. The experimental voltage profile is from ref 12 (b) Calculated Pourbaix diagram of $\mathrm{Na}_{3} \mathrm{Fe}_{2}\left(\mathrm{PO}_{4}\right)_{3}$. Regions containing solid phases are shaded with green color. (c) $\Delta G_{p b x}$ of $\mathrm{Na}_{x} \mathrm{Fe}_{2}\left(\mathrm{PO}_{4}\right)_{3}$ as a function of potential in neutral aqueous solution $(\mathrm{pH}=7)$. 


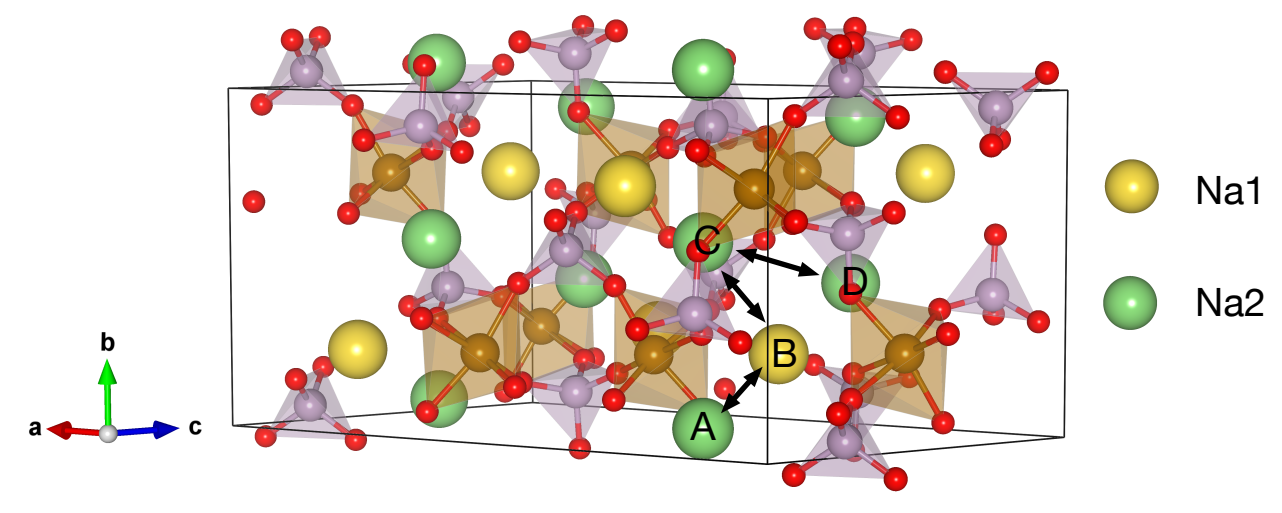

(a) Migration path

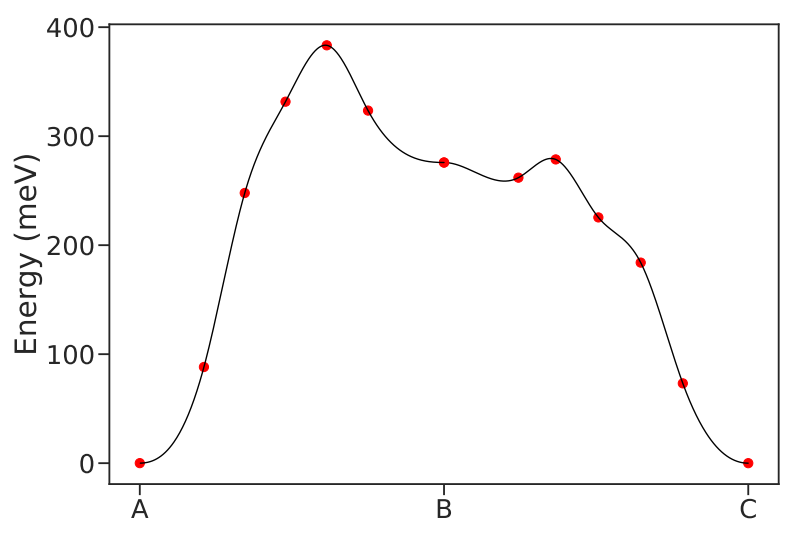

(b) $\mathrm{A} \rightarrow \mathrm{B} \rightarrow \mathrm{C}$

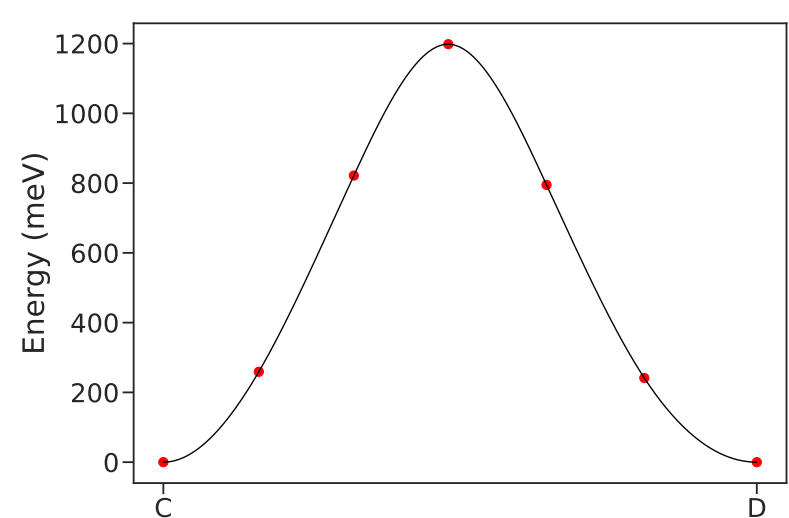

(c) $\mathrm{C} \rightarrow \mathrm{D}$

Figure S8: (a) Investigated $\mathrm{Na}$ vacancy diffusion paths in $\mathrm{Na}_{3} \mathrm{Fe}_{2}\left(\mathrm{PO}_{4}\right)_{3}$. Symmetrically distinct Na1 and Na2 are represented by green and yellow spheres, respectively. Purple tetrahedra and brown octahedra indicate $\mathrm{PO}_{4}$ and $\mathrm{FeO}_{6} \cdot$ (b)(c) Calculated CI-NEB migration barriers for selected percolating path. 


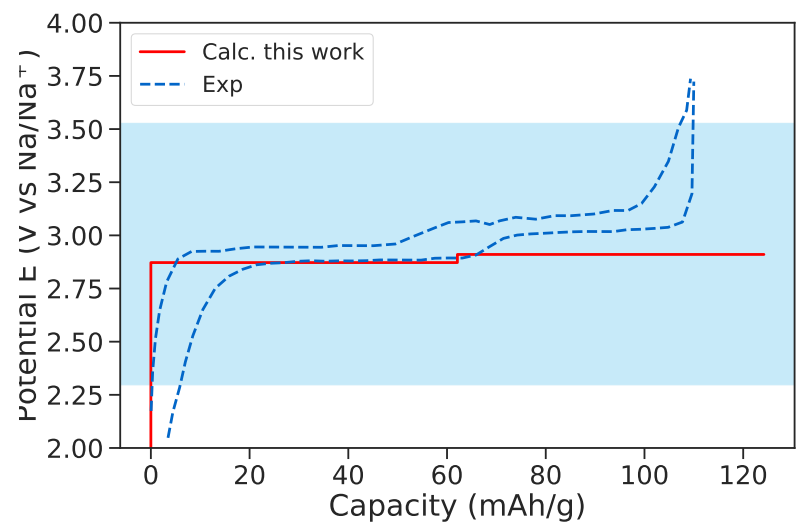

(a) Voltage profile of $\mathrm{Na}_{x} \mathrm{FePO}_{4} \mathrm{~F}$

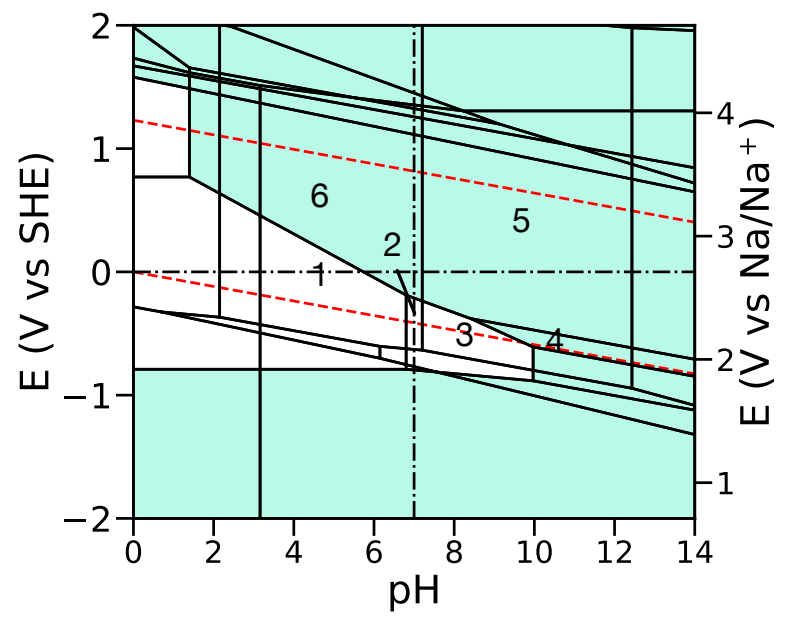

1. $\mathrm{Na}^{+}+\mathrm{Fe}^{2+}+\mathrm{H}_{2} \mathrm{PO}_{4}^{-}+\mathrm{F}_{2}^{2-}$

2. $\mathrm{Na}^{+}+\mathrm{Fe}(\mathrm{OH})^{+}+\mathrm{H}_{2} \mathrm{PO}_{4}^{-}+\mathrm{F}_{2}^{2-}$

3. $\mathrm{Na}^{+}+\mathrm{Fe}(\mathrm{OH})^{+}+\mathrm{HPO}_{4}{ }^{2-}+\mathrm{F}_{2}{ }^{2-}$

4. $\mathrm{Na}^{+}+\mathrm{Fe}_{3} \mathrm{O}_{4}(\mathrm{~s})+\mathrm{HPO}_{4}{ }^{2-}+\mathrm{F}_{2}{ }^{2-}$

5. $\mathrm{Na}^{+}+\mathrm{Fe}_{2} \mathrm{O}_{3}(\mathrm{~s})+\mathrm{HPO}_{4}{ }^{2-}+\mathrm{F}_{2}{ }^{2-}$

6. $\mathrm{Na}^{+}+\mathrm{Fe}_{2} \mathrm{O}_{3}(\mathrm{~s})+\mathrm{H}_{2} \mathrm{PO}_{4}^{-}+\mathrm{F}_{2}{ }^{2-}$

(b) Calculated Pourbaix diagram of $\mathrm{Na}_{2} \mathrm{FePO}_{4} \mathrm{~F}$

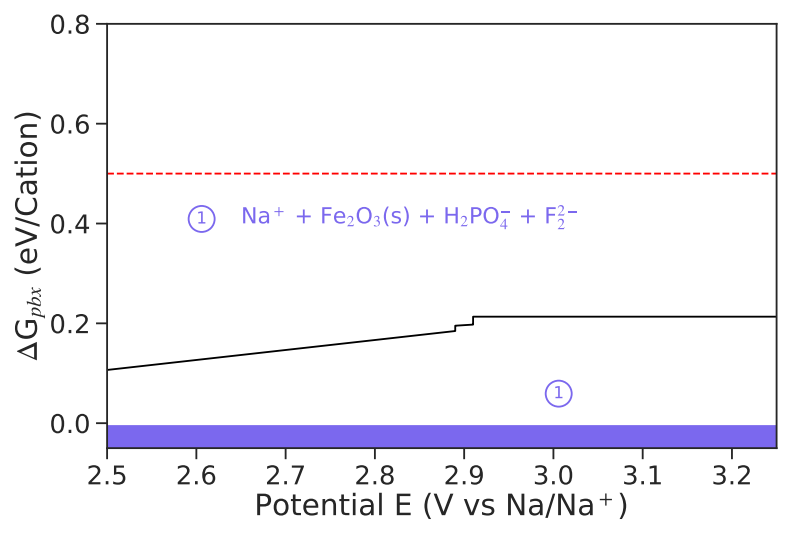

(c) $\Delta G_{p b x}$ vs $\mathrm{E}$ of $\mathrm{Na}_{\mathrm{x}} \mathrm{FePO}_{4} \mathrm{~F}$

Figure S9: (a) Voltage profile of $\mathrm{Na}_{2} \mathrm{FePO}_{4} \mathrm{~F}$. Electrochemical window $(\mathrm{pH}=7)$ is shaded with blue color. The experimental voltage profile is from ref 13. (b) Calculated Pourbaix diagram of $\mathrm{Na}_{2} \mathrm{FePO}_{4} \mathrm{~F}$. Regions containing solid phases are shaded with green color. (c) $\Delta G_{p b x}$ of $\mathrm{Na}_{\mathrm{x}} \mathrm{FePO}_{4} \mathrm{~F}$ as a function of potential in neutral aqueous solution $(\mathrm{pH}=7)$. 

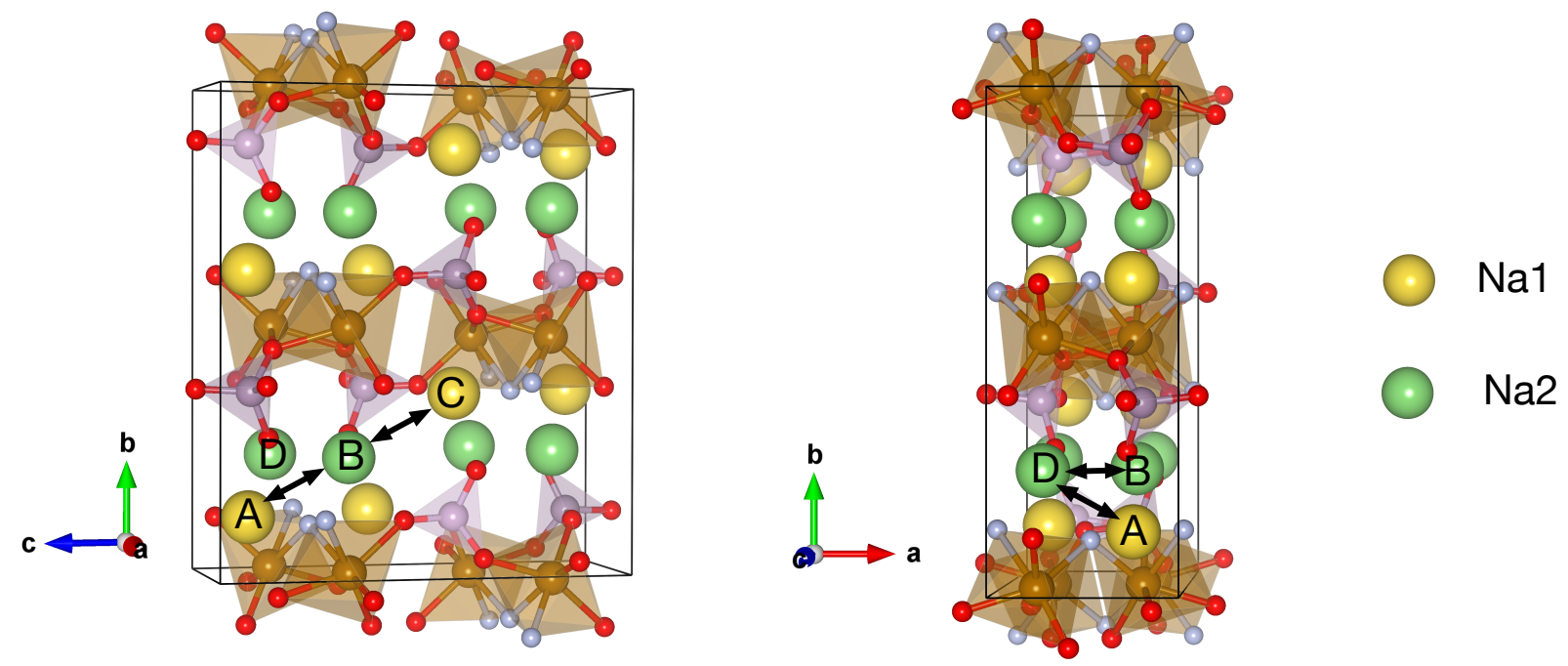

(a) Migration path

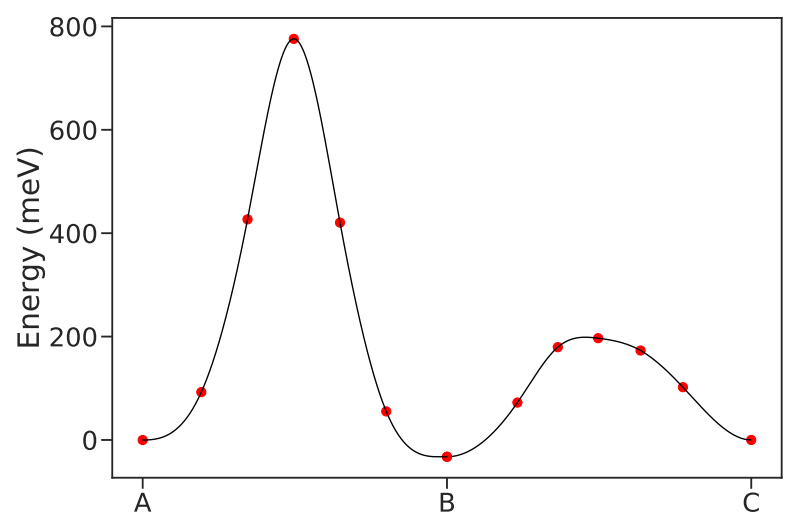

(b) $\mathrm{A} \rightarrow \mathrm{B} \rightarrow \mathrm{C}$

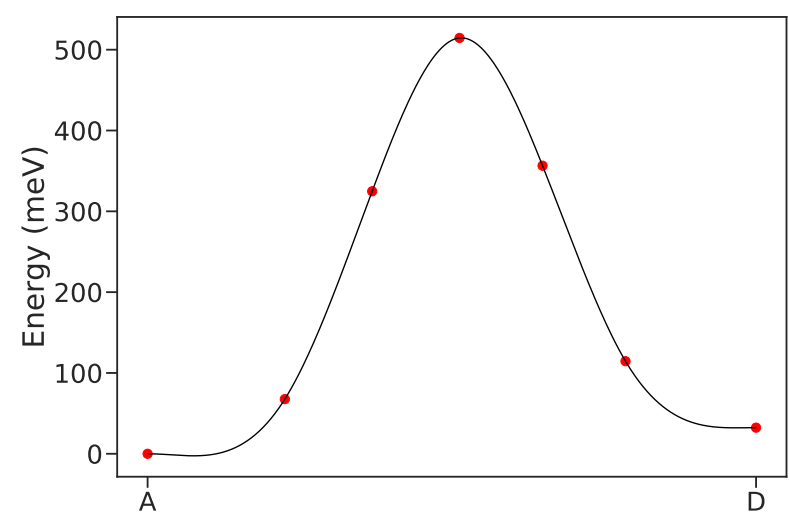

(c) $\mathrm{A} \rightarrow \mathrm{D}$

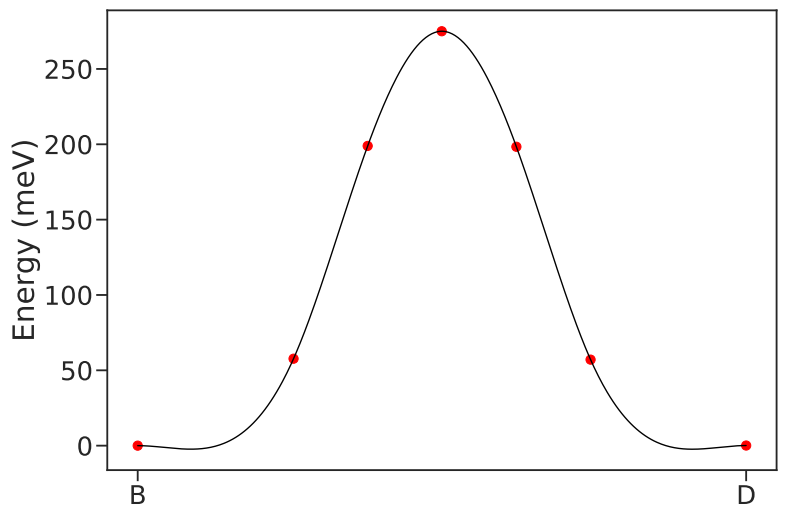

(d) $\mathrm{B} \rightarrow \mathrm{D}$

Figure S10: (a) Investigated $\mathrm{Na}$ vacancy diffusion paths in $\mathrm{Na}_{2} \mathrm{FePO}_{4} \mathrm{~F}$. Symmetrically distinct $\mathrm{Na} 1$ and $\mathrm{Na} 2$ are represented by green and yellow spheres, respectively. Purple tetrahedra and brown octahedra indicate $\mathrm{PO}_{4}$ and $\mathrm{FeO}_{4} \mathrm{~F}_{2}$. (b)(c)(d) Calculated CI-NEB migration barriers for selected percolating path. 


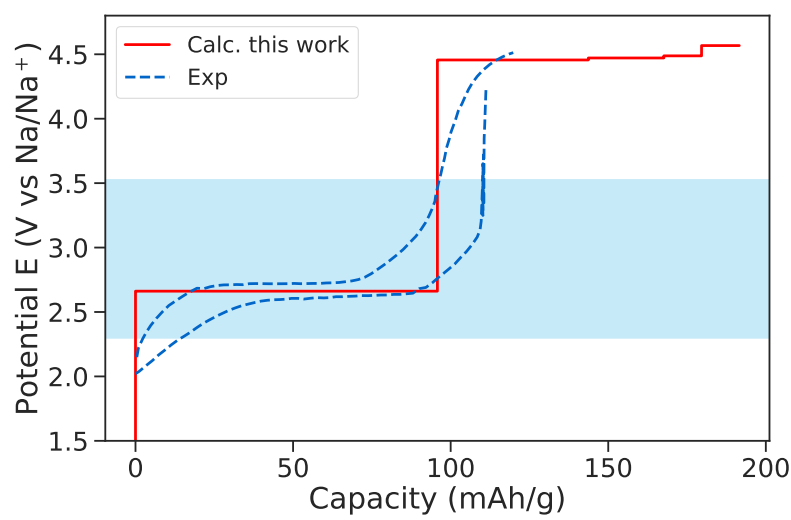

(a) Voltage profile of $\mathrm{Na}_{x} \mathrm{FeCO}_{3} \mathrm{PO}_{4}$

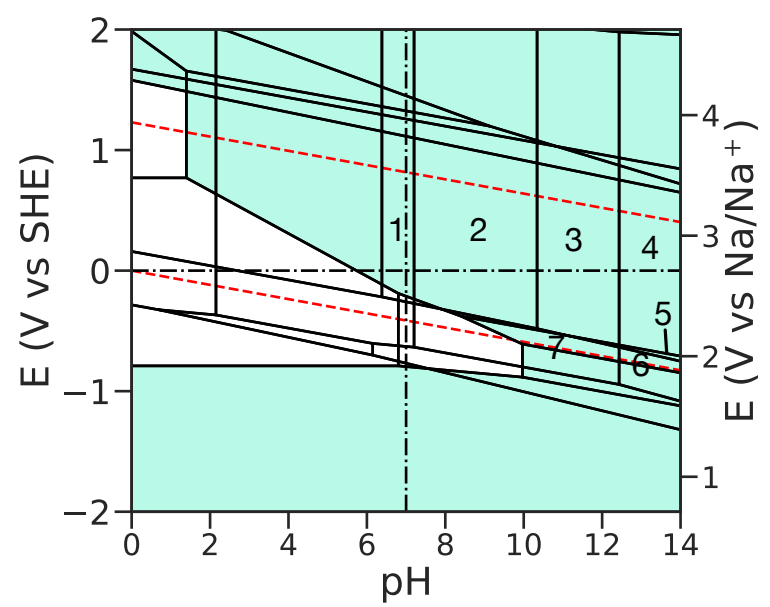

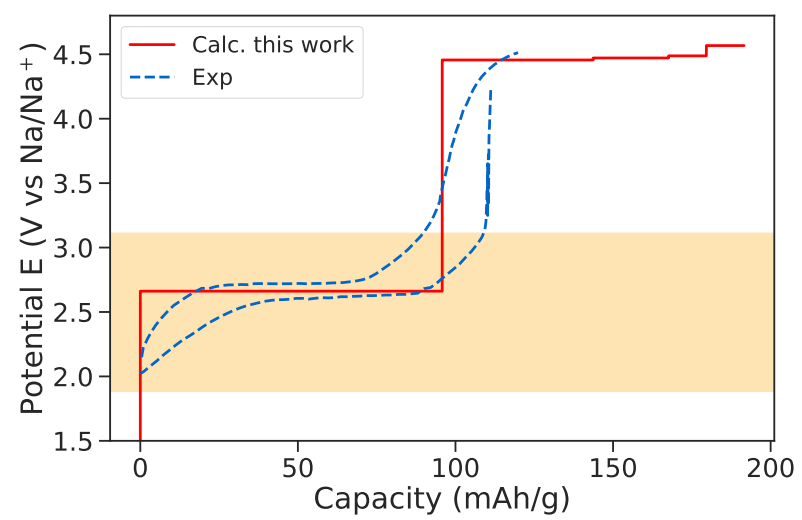

(b) Voltage profile of $\mathrm{Na}_{x} \mathrm{FeCO}_{3} \mathrm{PO}_{4}$

(c) Calculated Pourbaix diagram of $\mathrm{Na}_{3} \mathrm{FeCO}_{3} \mathrm{PO}_{4}$

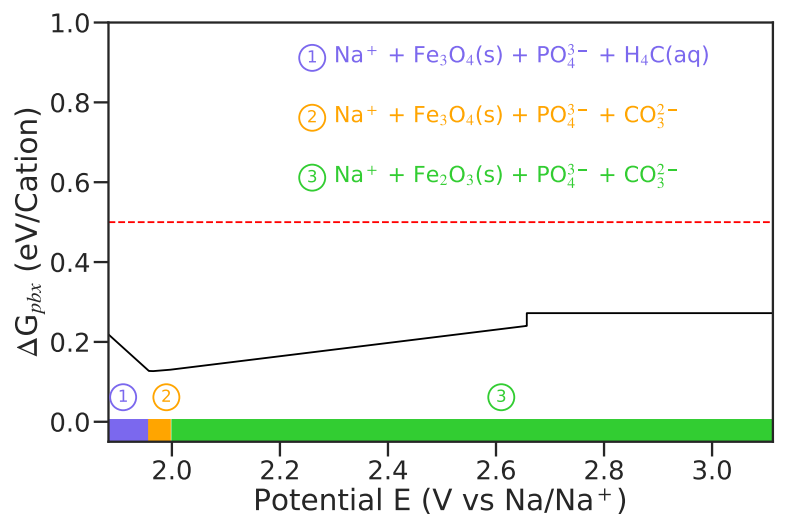

(d) $\Delta G_{p b x}$ vs $\mathrm{E}$ of $\mathrm{Na}_{x} \mathrm{FeCO}_{3} \mathrm{PO}_{4}$

Figure S11: (a) Voltage profile of $\mathrm{Na}_{x} \mathrm{FeCO}_{3} \mathrm{PO}_{4}$. Electrochemical window at $\mathrm{pH}=7$ and $\mathrm{pH}=14$ is shaded with blue and orange color, respectively. The experimental voltage profile is from ref 14 (b) Calculated Pourbaix diagram of $\mathrm{Na}_{3} \mathrm{FeCO}_{3} \mathrm{PO}_{4}$. Regions containing solid phases are shaded with green color. (c) $\Delta G_{p b x}$ of $\mathrm{Na}_{x} \mathrm{FeCO}_{3} \mathrm{PO}_{4}$ as a function of potential in basic aqueous solution $(\mathrm{pH}=12)$. 


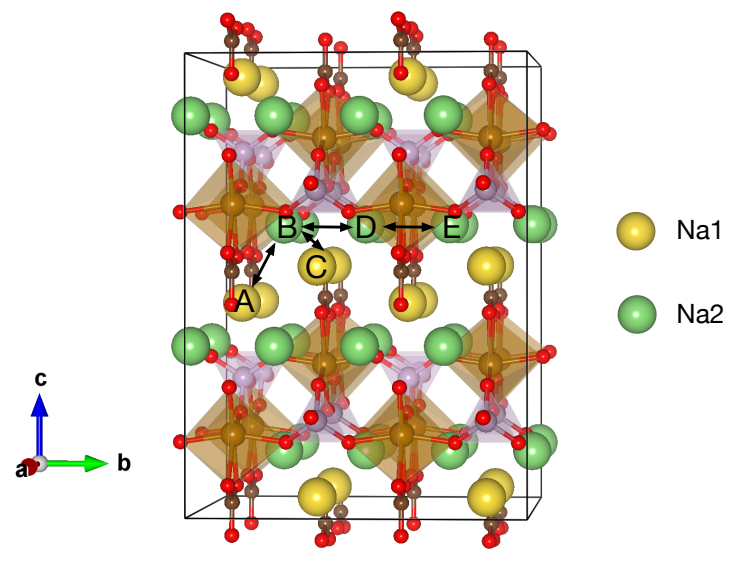

(a) Migration path

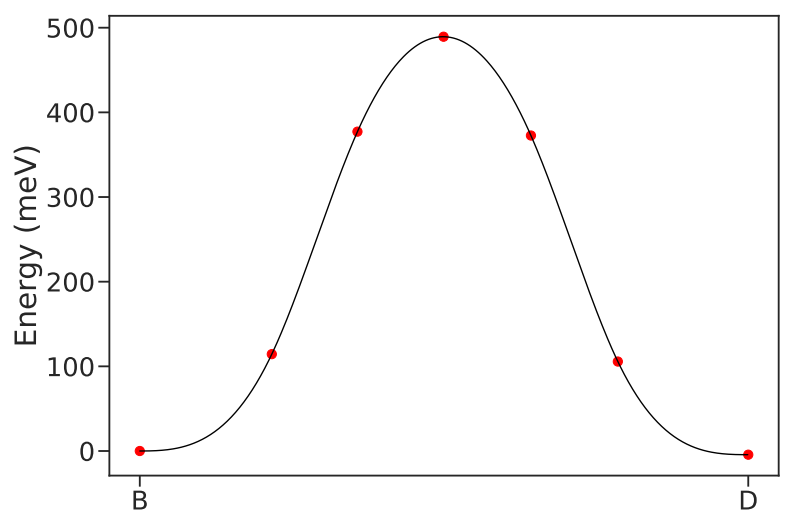

(c) $\mathrm{B} \rightarrow \mathrm{D}$

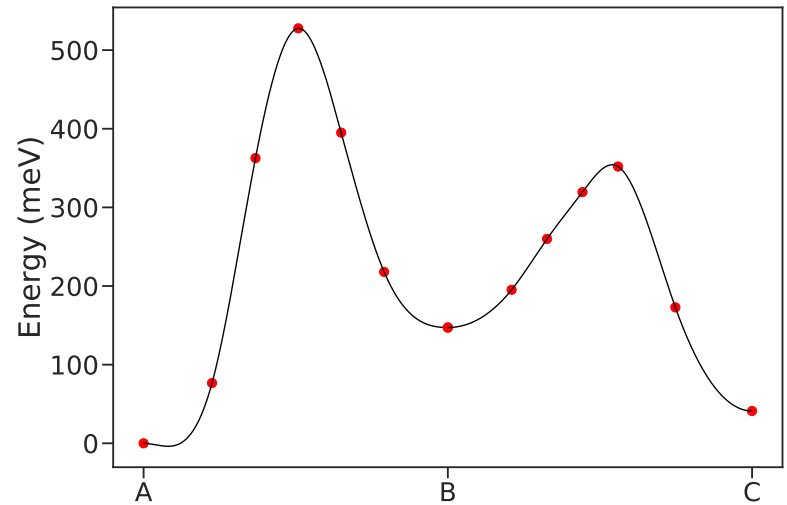

(b) $\mathrm{A} \rightarrow \mathrm{B} \rightarrow \mathrm{C}$

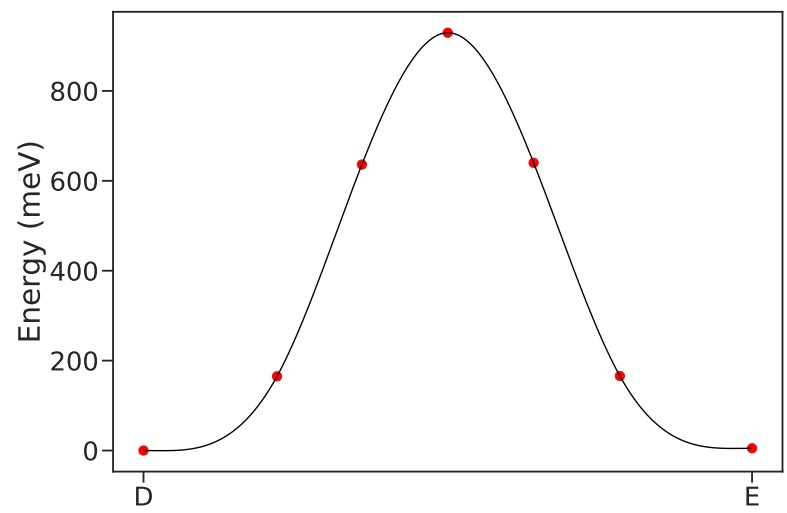

(d) $\mathrm{D} \rightarrow \mathrm{E}$

Figure S12: (a) Investigated $\mathrm{Na}$ vacancy diffusion paths in $\mathrm{Na}_{3} \mathrm{FeCO}_{3} \mathrm{PO}_{4}$. Symmetrically distinct $\mathrm{Na} 1$ and $\mathrm{Na} 2$ are represented by green and yellow spheres, respectively. Purple tetrahedra and brown octahedra indicate $\mathrm{PO}_{4}$ and $\mathrm{FeO}_{6}$. (b)(c)(d) Calculated CI-NEB migration barriers for selected percolating path. 


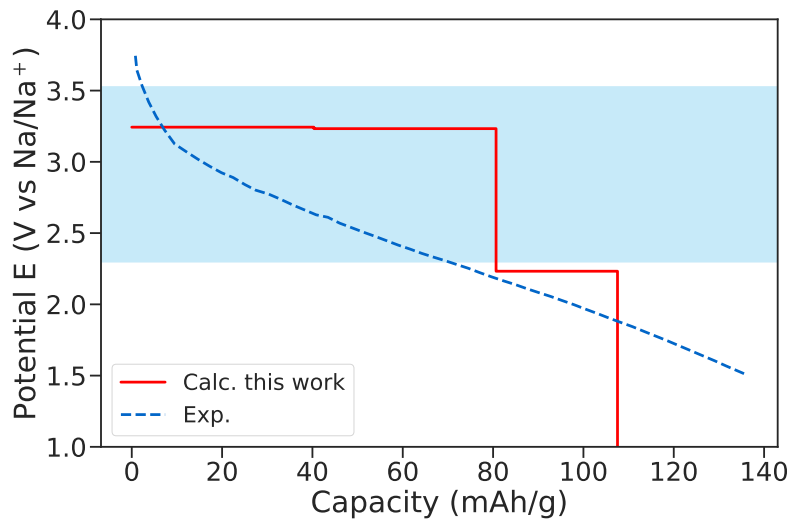

(a) Voltage profile of $\mathrm{Na}_{x} \mathrm{Fe}_{3}\left(\mathrm{PO}_{4}\right)_{3}$

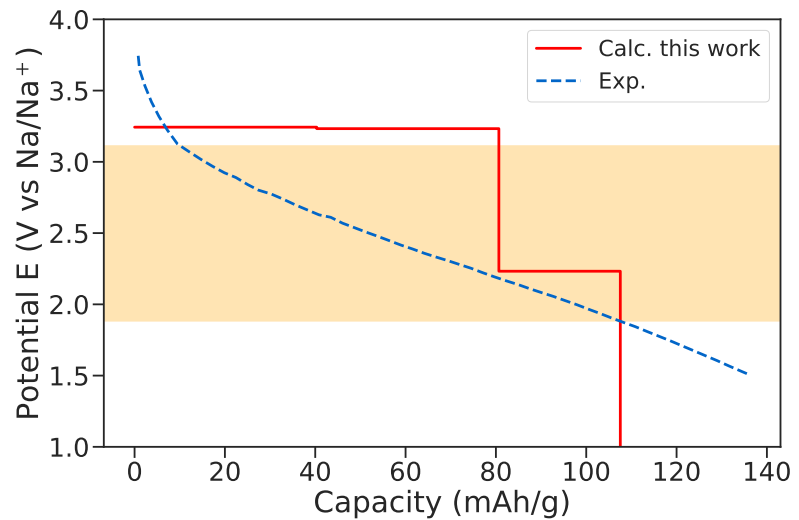

(b) Voltage profile of $\mathrm{Na}_{x} \mathrm{Fe}_{3}\left(\mathrm{PO}_{4}\right)_{3}$

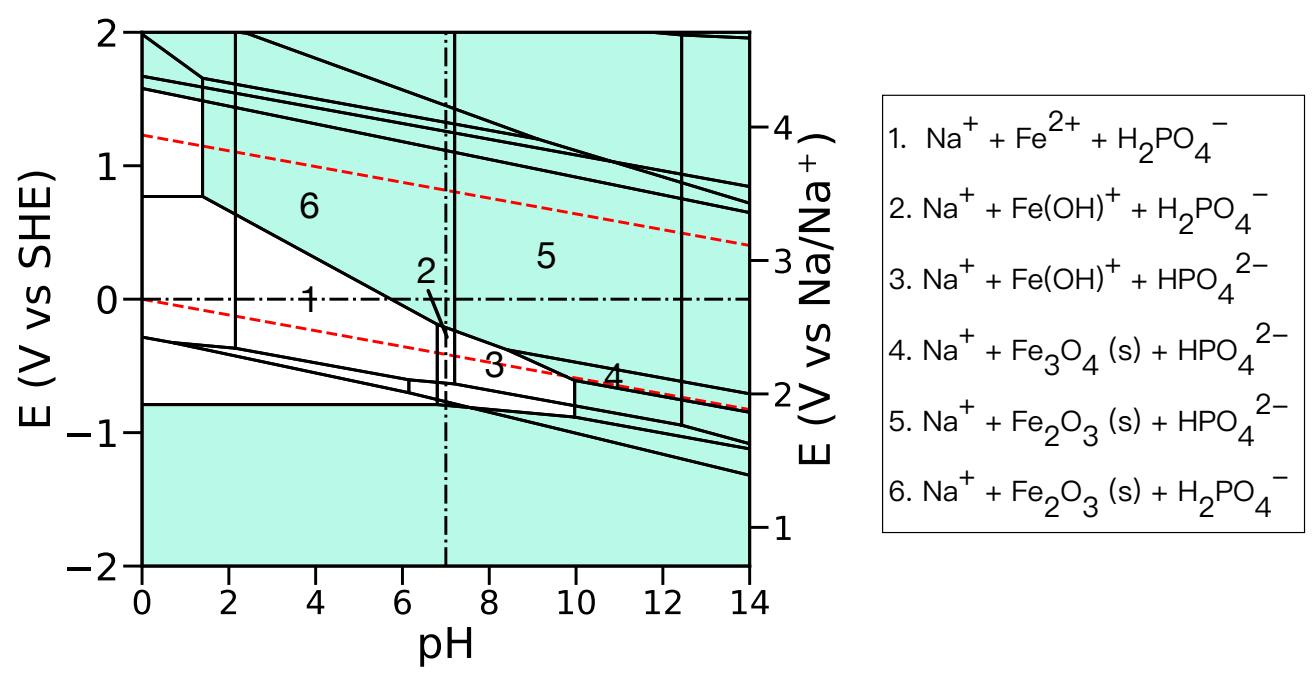

(c) Calculated Pourbaix diagram of $\mathrm{Na}_{2} \mathrm{Fe}_{3}\left(\mathrm{PO}_{4}\right)_{3}$ 


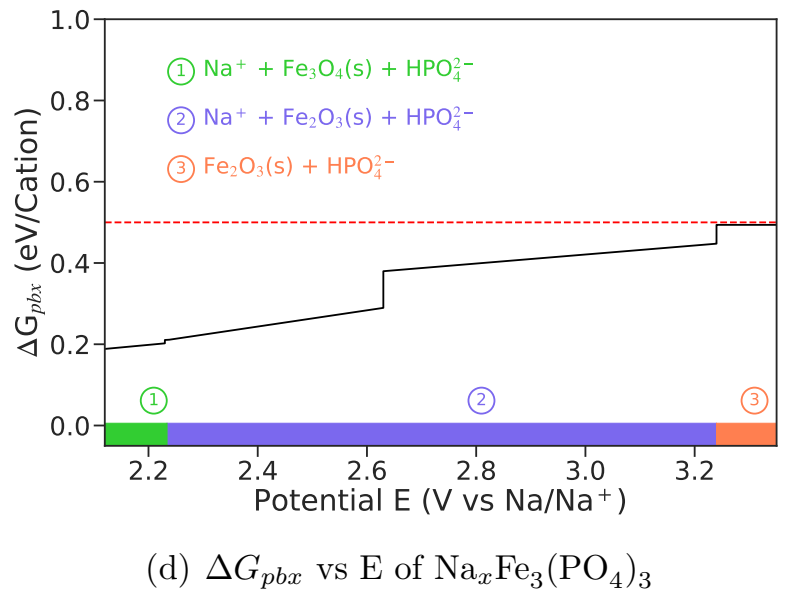

Figure S13: Voltage profile of $\mathrm{Na}_{x} \mathrm{Fe}_{3}\left(\mathrm{PO}_{4}\right)_{3}$. Electrochemical window at (a) $\mathrm{pH}=7$ and (b) $\mathrm{pH}=14$ is shaded with blue and orange color, respectively. The experimental voltage profile is from ref 15. (b) Calculated Pourbaix diagram of $\mathrm{Na}_{2} \mathrm{Fe}_{3}\left(\mathrm{PO}_{4}\right)_{3}$. Regions containing solid phases are shaded with green color. (c) $\Delta G_{p b x}$ of $\mathrm{Na}_{x} \mathrm{Fe}_{3}\left(\mathrm{PO}_{4}\right)_{3}$ as a function of potential in basic aqueous solution $(\mathrm{pH}=14)$. 


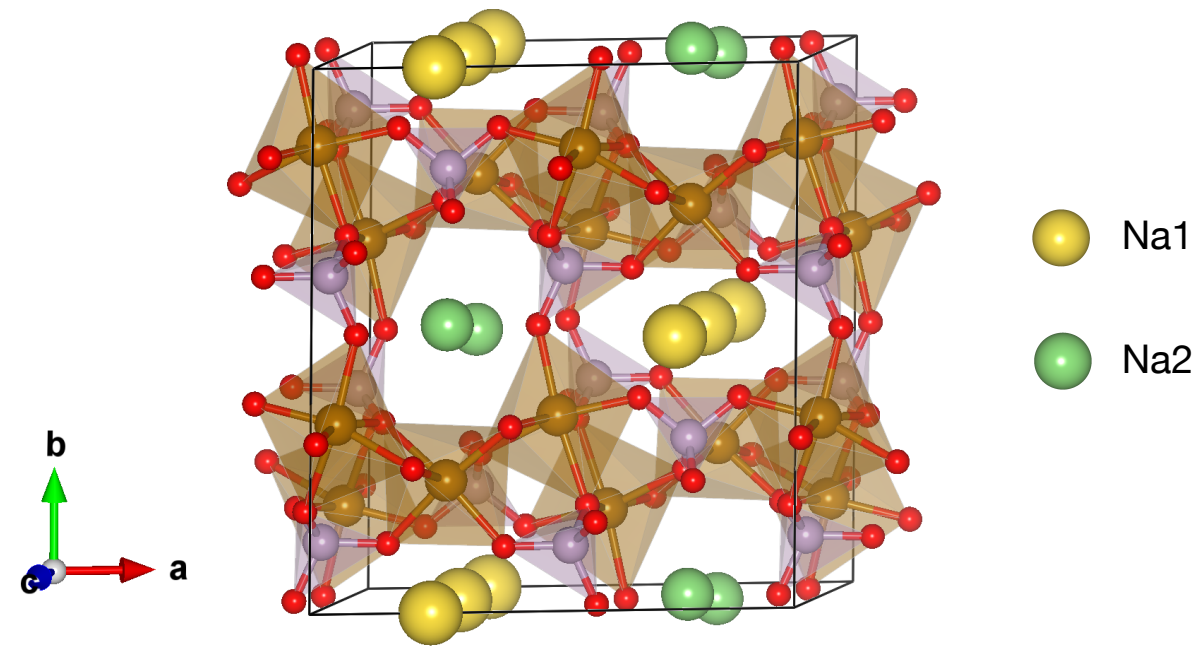

(a) Migration path

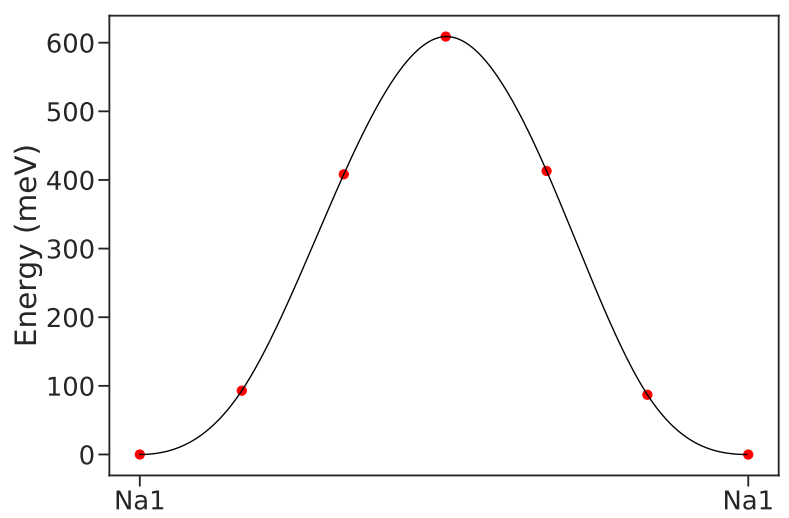

(b) $\mathrm{Na} 1 \rightarrow \mathrm{Na} 1$

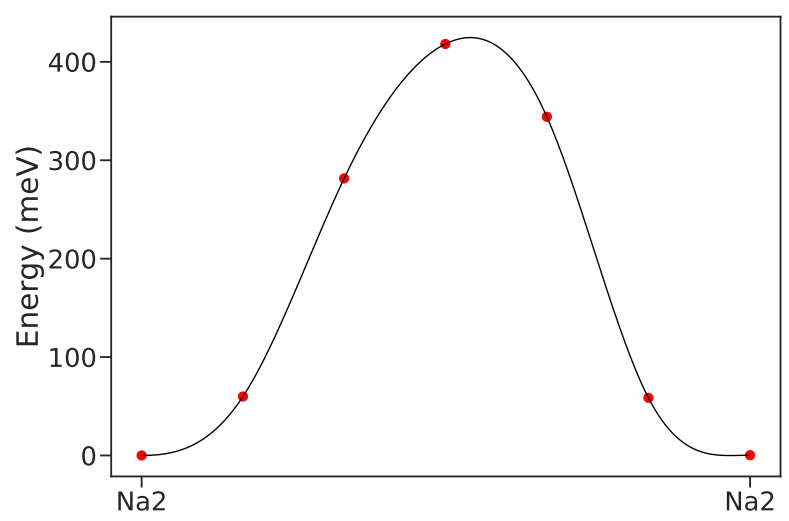

(c) $\mathrm{Na} 2 \rightarrow \mathrm{Na} 2$

Figure S14: (a) Investigated $\mathrm{Na}$ vacancy diffusion paths in $\mathrm{Na}_{2} \mathrm{Fe}_{3}\left(\mathrm{PO}_{4}\right)_{3}$. Symmetrically distinct $\mathrm{Na} 1$ and $\mathrm{Na} 2$ are represented by green and yellow spheres, respectively. Purple tetrahedra and brown octahedra indicate $\mathrm{PO}_{4}$ and $\mathrm{FeO}_{6}$. (b)(c) Calculated CI-NEB migration barriers for selected percolating path. 


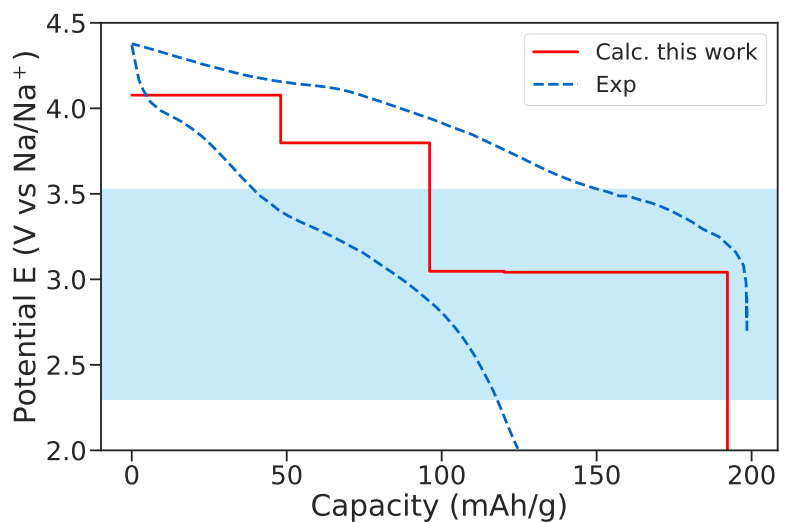

(a) Voltage profile of $\mathrm{Na}_{x} \mathrm{MnCO}_{3} \mathrm{PO}_{4}$

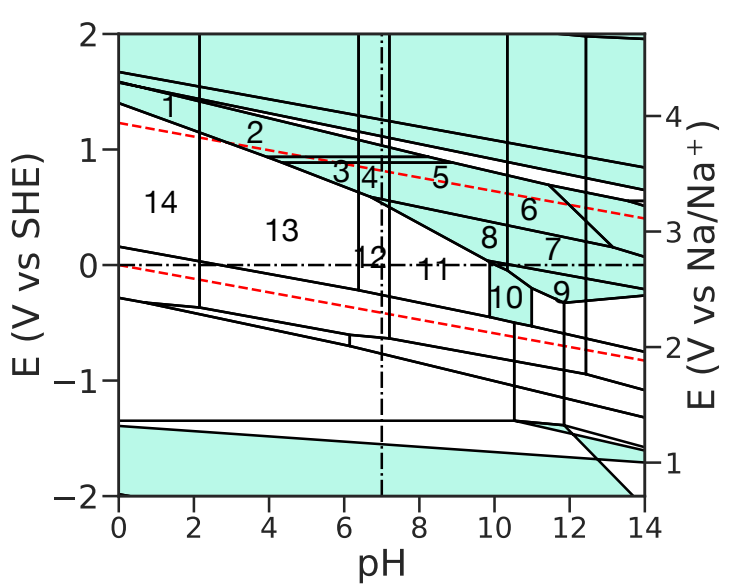

(c) Calculated Pourbaix diagram of $\mathrm{Na}_{3} \mathrm{MnCO}_{3} \mathrm{PO}_{4}$

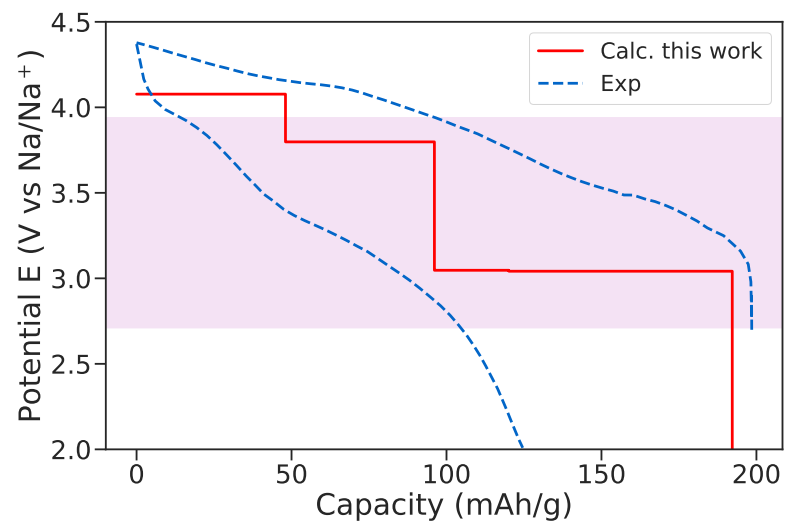

(b) Voltage profile of $\mathrm{Na}_{x} \mathrm{MnCO}_{3} \mathrm{PO}_{4}$

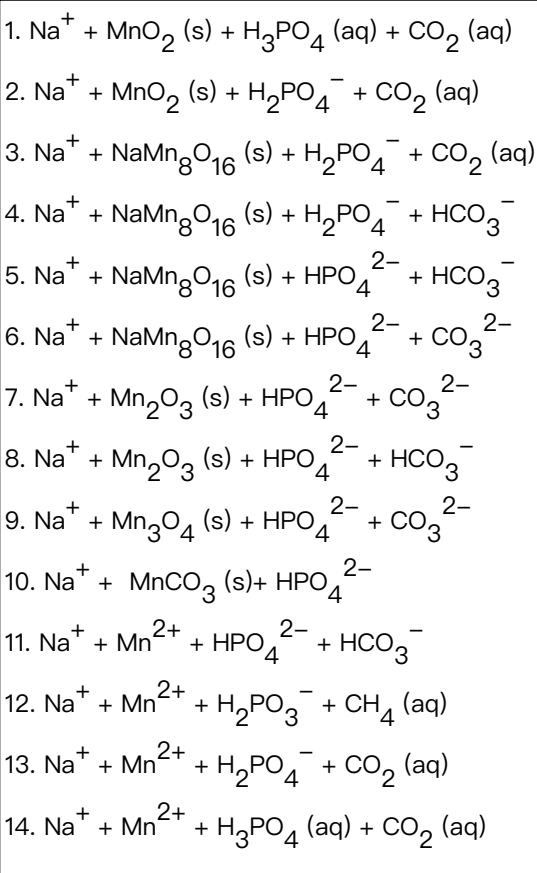




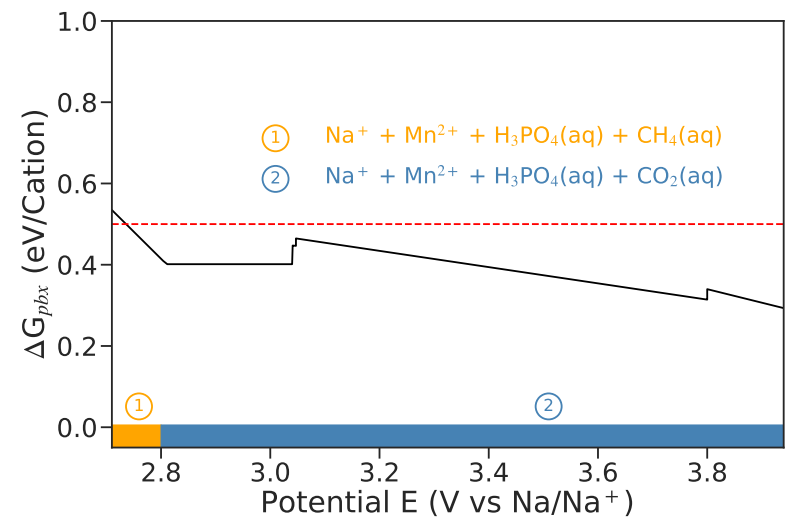

(d) $\Delta G_{p b x}$ vs $\mathrm{E}$ of $\mathrm{Na}_{x} \mathrm{MnCO}_{3} \mathrm{PO}_{4}$ at $\mathrm{pH}=1$

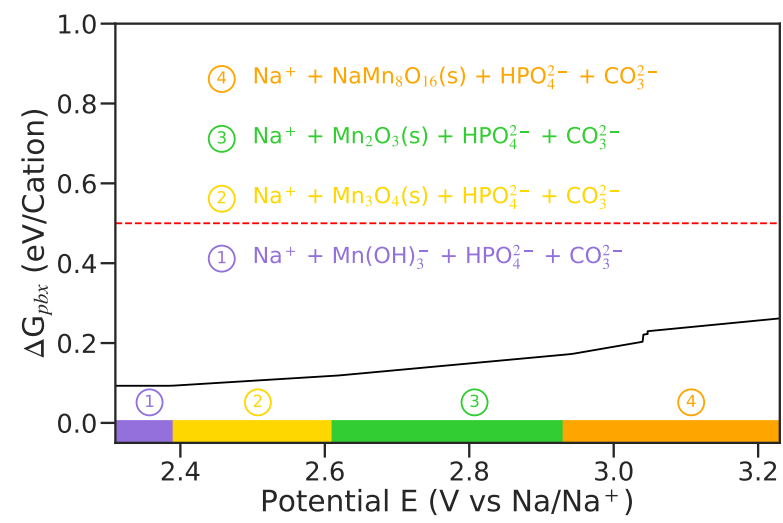

(e) $\Delta G_{p b x}$ vs $\mathrm{E}$ of $\mathrm{Na}_{x} \mathrm{MnCO}_{3} \mathrm{PO}_{4}$ at $\mathrm{pH}=12$

Figure S15: Voltage profile of $\mathrm{Na}_{x} \mathrm{MnCO}_{3} \mathrm{PO}_{4}$. Electrochemical window at (a) $\mathrm{pH}=7$ and (b) $\mathrm{pH}=0$ is shaded with blue and pink color, respectively. The experimental voltage profile is from ref 16. (b) Calculated Pourbaix diagram of $\mathrm{Na}_{3} \mathrm{MnCO}_{3} \mathrm{PO}_{4}$. Regions containing solid phases are shaded with green color. $\Delta G_{p b x}$ of $\mathrm{Na}_{x} \mathrm{MnCO}_{3} \mathrm{PO}_{4}$ as a function of potential (c) in acidic aqueous solution $(\mathrm{pH}=1)$ and $(\mathrm{d})$ in basic aqueous solution $(\mathrm{pH}=12)$. 


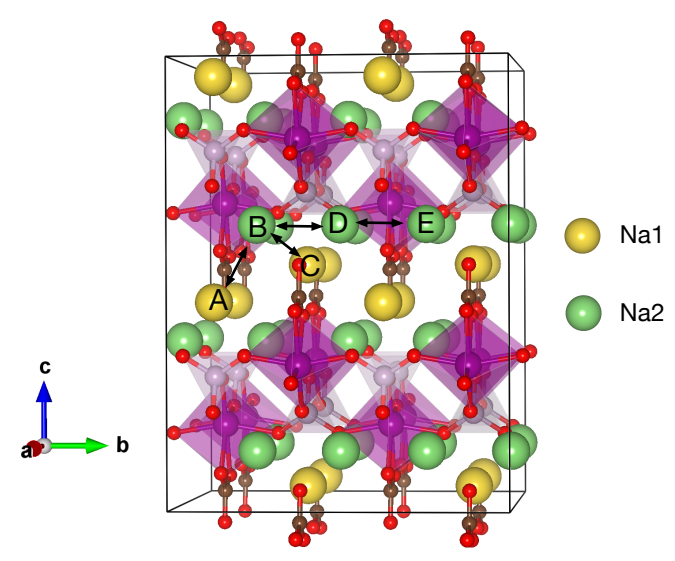

(a) Migration path

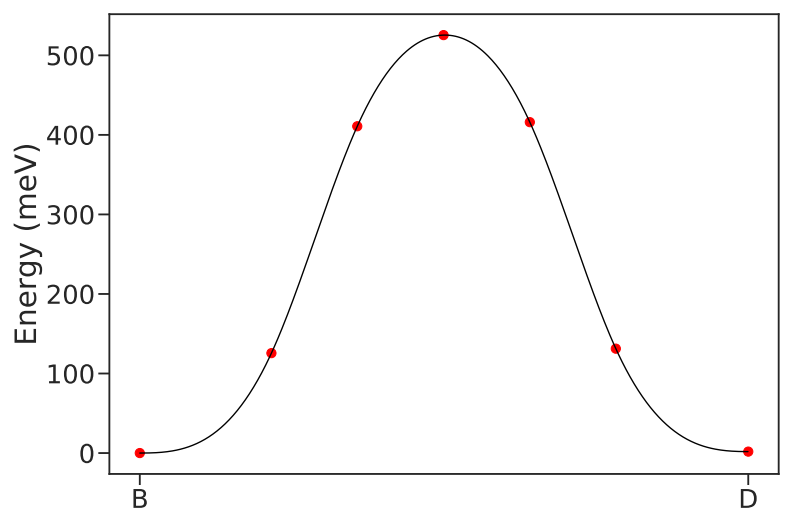

(c) $\mathrm{B} \rightarrow \mathrm{D}$

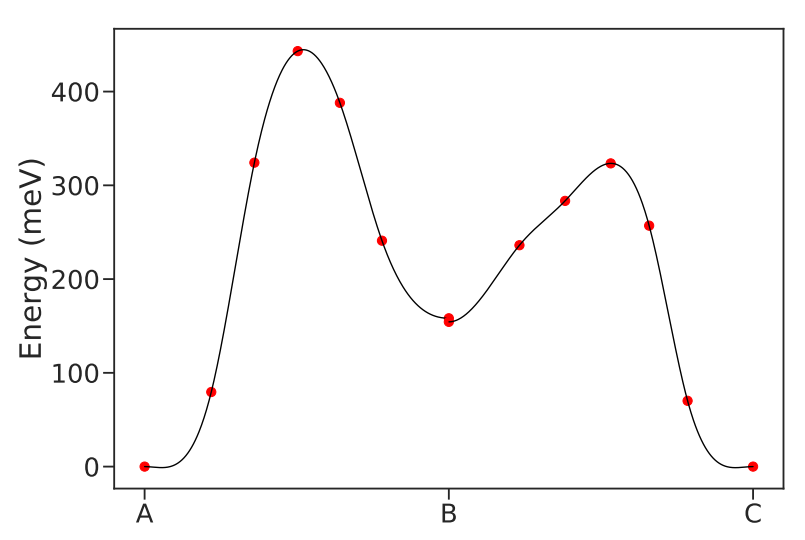

(b) $\mathrm{A} \rightarrow \mathrm{B} \rightarrow \mathrm{C}$

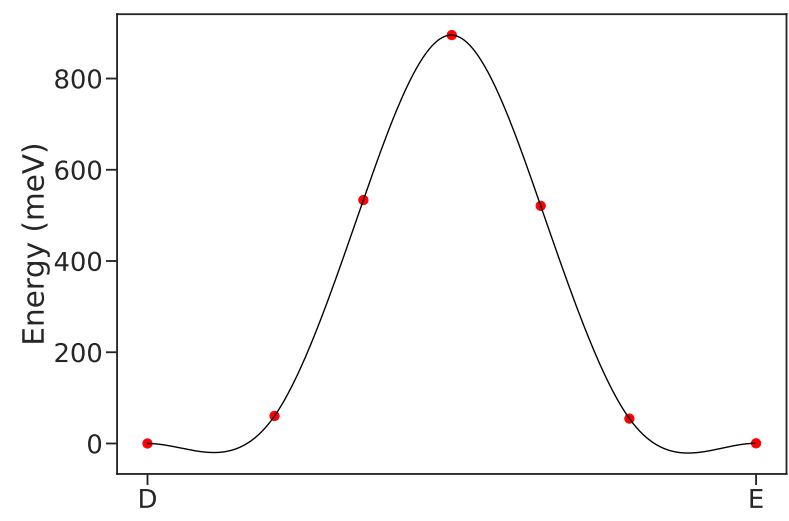

(d) $\mathrm{D} \rightarrow \mathrm{E}$

Figure S16: (a) Investigated $\mathrm{Na}$ vacancy diffusion paths in $\mathrm{Na}_{3} \mathrm{MnCO}_{3} \mathrm{PO}_{4}$. Symmetrically distinct $\mathrm{Na} 1$ and $\mathrm{Na} 2$ are represented by green and yellow spheres, respectively. Purple tetrahedra and violet octahedra indicate $\mathrm{PO}_{4}$ and $\mathrm{MnO}_{6}$. (b)(c)(d) Calculated CI-NEB migration barriers for selected percolating path. 


\section{References}

(1) Cao, Y.; Xiao, L.; Wang, W.; Choi, D.; Nie, Z.; Yu, J.; Saraf, L. V.; Yang, Z.; Liu, J. Reversible sodium ion insertion in single crystalline manganese oxide nanowires with long cycle life. Advanced Materials 2011, 23, 3155-3160.

(2) Kim, H.; Kim, D. J.; Seo, D.-H.; Yeom, M. S.; Kang, K.; Kim, D. K.; Jung, Y. Ab initio study of the sodium intercalation and intermediate phases in $\mathrm{Na}_{0.44} \mathrm{MnO}_{2}$ for sodium-ion battery. Chemistry of Materials 2012, 24, 1205-1211.

(3) Saravanan, K.; Mason, C. W.; Rudola, A.; Wong, K. H.; Balaya, P. The first report on excellent cycling stability and superior rate capability of $\mathrm{Na}_{3} \mathrm{~V}_{2}\left(\mathrm{PO}_{4}\right)_{3}$ for sodium ion batteries. Advanced Energy Materials 2013, 3, 444-450.

(4) Lim, S. Y.; Kim, H.; Shakoor, R.; Jung, Y.; Choi, J. W. Electrochemical and thermal properties of NASICON structured $\mathrm{Na}_{3} \mathrm{~V}_{2}\left(\mathrm{PO}_{4}\right)_{3}$ as a sodium rechargeable battery cathode: a combined experimental and theoretical study. Journal of The Electrochemical Society 2012, 159, A1393.

(5) Kim, H.; Shakoor, R.; Park, C.; Lim, S. Y.; Kim, J.-S.; Jo, Y. N.; Cho, W.; Miyasaka, K.; Kahraman, R.; Jung, Y., et al. $\mathrm{Na}_{2} \mathrm{FeP}_{2} \mathrm{O}_{7}$ as a promising iron-based pyrophosphate cathode for sodium rechargeable batteries: a combined experimental and theoretical study. Advanced Functional Materials 2013, 23, 1147-1155.

(6) Boucher, F.; Gaubicher, J.; Cuisinier, M.; Guyomard, D.; Moreau, P. Elucidation of the $\mathrm{Na}_{2 / 3} \mathrm{FePO}_{4}$ and $\mathrm{Li}_{2 / 3} \mathrm{FePO}_{4}$ intermediate superstructure revealing a pseudouniform ordering in 2D. Journal of the American Chemical Society 2014, 136, 9144-9157.

(7) Saracibar, A.; Carrasco, J.; Saurel, D.; Galceran, M.; Acebedo, B.; Anne, H.; Lepoitevin, M.; Rojo, T.; Cabanas, M. C. Investigation of sodium insertion-extraction in olivine $\mathrm{Na}_{x} \mathrm{FePO}_{4}(0 \leq \mathrm{x} \leq 1)$ using first-principles calculations. Physical Chemistry Chemical Physics 2016, 18, 13045-13051. 
(8) Oh, S.-M.; Myung, S.-T.; Hassoun, J.; Scrosati, B.; Sun, Y.-K. Reversible $\mathrm{NaFePO}_{4}$ electrode for sodium secondary batteries. Electrochemistry Communications 2012, 22, $149-152$.

(9) Li, Q.; Liu, Z.; Zheng, F.; Liu, R.; Lee, J.; Xu, G.-L.; Zhong, G.; Hou, X.; Fu, R.; Chen, Z., et al. Identifying the structural evolution of the sodium ion battery $\mathrm{Na}_{2} \mathrm{FePO}_{4} \mathrm{~F}$ cathode. Angewandte Chemie 2018, 130, 12094-12099.

(10) Shinagawa, C.; Morikawa, Y.; Nishimura, S.-i.; Ushiyama, H.; Yamada, A.; Yamashita, K. A Theoretical study on the charge and discharge states of Na-ion battery cathode material, $\mathrm{Na}_{1+x} \mathrm{FePO}_{4} \mathrm{~F}$. Journal of computational chemistry 2019, 40, $237-246$.

(11) Jung, Y. H.; Lim, C. H.; Kim, J.-H.; Kim, D. K. $\mathrm{Na}_{2} \mathrm{FeP}_{2} \mathrm{O}_{7}$ as a positive electrode material for rechargeable aqueous sodium-ion batteries. Rsc Advances 2014, 4, 97999802.

(12) Rajagopalan, R.; Chen, B.; Zhang, Z.; Wu, X.-L.; Du, Y.; Huang, Y.; Li, B.; Zong, Y.; Wang, J.; Nam, G.-H., et al. Improved reversibility of $\mathrm{Fe}^{3+} / \mathrm{Fe}^{4+}$ redox couple in sodium super ion conductor type $\mathrm{Na}_{3} \mathrm{Fe}_{2}\left(\mathrm{PO}_{4}\right)_{3}$ for sodium-ion batteries. Advanced Materials 2017, 29, 1605694.

(13) Kawabe, Y.; Yabuuchi, N.; Kajiyama, M.; Fukuhara, N.; Inamasu, T.; Okuyama, R.; Nakai, I.; Komaba, S. Synthesis and electrode performance of carbon coated $\mathrm{Na}_{2} \mathrm{FePO}_{4} \mathrm{~F}$ for rechargeable $\mathrm{Na}$ batteries. Electrochemistry Communications 2011, 13, $1225-1228$.

(14) Huang, W.; Zhou, J.; Li, B.; Ma, J.; Tao, S.; Xia, D.; Chu, W.; Wu, Z. Detailed investigation of $\mathrm{Na}_{2.24} \mathrm{FePO}_{4} \mathrm{CO}_{3}$ as a cathode material for Na-ion batteries. Scientific reports 2014, 4, 4188 . 
(15) Huang, W.; Li, B.; Saleem, M. F.; Wu, X.; Li, J.; Lin, J.; Xia, D.; Chu, W.; Wu, Z. Self-Assembled Alluaudite $\mathrm{Na}_{2} \mathrm{Fe}_{3-x} \mathrm{Mn}_{x}\left(\mathrm{PO}_{4}\right)_{3}$ Micro/Nanocompounds for SodiumIon Battery Electrodes: A New Insight into Their Electronic and Geometric Structure. Chemistry-A European Journal 2015, 21, 851-860.

(16) Chen, H.; Hao, Q.; Zivkovic, O.; Hautier, G.; Du, L.-S.; Tang, Y.; Hu, Y.-Y.; Ma, X.; Grey, C. P.; Ceder, G. Sidorenkite $\left(\mathrm{Na}_{3} \mathrm{MnPO}_{4} \mathrm{CO}_{3}\right)$ : a new intercalation cathode material for Na-ion batteries. Chemistry of Materials 2013, 25, 2777-2786. 